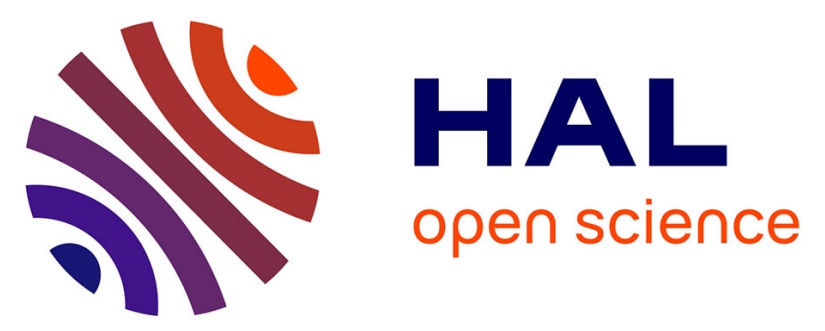

\title{
An agent-based model for exploring the combined effects of social and demographic changes on the concentration and hierarchy of rural settlement patterns in North-Western Europe during the Middle Ages (800-1200 CE)
}

Cécile Tannier, Robin Cura, Samuel Leturcq, Elisabeth Zadora-Rio

\section{To cite this version:}

Cécile Tannier, Robin Cura, Samuel Leturcq, Elisabeth Zadora-Rio. An agent-based model for exploring the combined effects of social and demographic changes on the concentration and hierarchy of rural settlement patterns in North-Western Europe during the Middle Ages (800-1200 CE). Journal of Anthropological Archaeology, 2020, 59, pp.101204. 10.1016/j.jaa.2020.101204 . hal-02918535

\author{
HAL Id: hal-02918535 \\ https://hal.science/hal-02918535
}

Submitted on 1 Sep 2020

HAL is a multi-disciplinary open access archive for the deposit and dissemination of scientific research documents, whether they are published or not. The documents may come from teaching and research institutions in France or abroad, or from public or private research centers.
L'archive ouverte pluridisciplinaire HAL, est destinée au dépôt et à la diffusion de documents scientifiques de niveau recherche, publiés ou non, émanant des établissements d'enseignement et de recherche français ou étrangers, des laboratoires publics ou privés. 


\section{An agent-based model for exploring the combined effects of social and demographic changes on the concentration and hierarchy of rural settlement patterns in North-Western Europe during the Middle Ages (800-1200 CE)}

Cécile Tannier (corresponding author)

ThéMA \& Chrono-Environnement, CNRS - University Bourgogne Franche-Comté

10 32, rue Mégevand

F-25 030 Besançon cedex, France

cecile.tannier@univ-fcomte.fr

\section{Robin Cura}

15 Géographie-cités, CNRS - University Paris 1 Panthéon-Sorbonne

Campus Condorcet

5, cours des Humanités

F-93 322 Aubervilliers cedex, France

robin.cura@parisgeo.cnrs.fr

20

\section{Samuel Leturcq}

CITERES-LAT, CNRS - University François Rabelais

MSH Villes et Territoires

BP 60449

25 F-37 204 Tours cedex 03, France

samuel.leturcq@univ-tours.fr

\section{Elisabeth Zadora-Rio}

CITERES-LAT, CNRS - University François Rabelais

30 MSH Villes et Territoires

BP 60449

F-37 204 Tours cedex 03, France

e.zadora.rio@gmail.com

This is a postprint version, the definitive version of this paper is :

Cécile Tannier, Robin Cura, Samuel Leturcq, Elisabeth Zadora-Rio. An agent-based model for exploring the combined effects of social and demographic changes on the concentration and hierarchy of rural settlement patterns in North-Western Europe during the Middle Ages (800-1200 CE). Journal of Anthropological Archaeology, Elsevier, 2020, 59, pp.101204 - 10.1016/i.jaa.2020.101204 


\title{
An agent-based model for exploring the combined effects of social and demographic changes on the concentration and hierarchy of rural settlement patterns in North-Western Europe during the Middle Ages (800-1200 CE)
}

\begin{abstract}
Rural settlement patterns in North-Western Europe in 800 CE were scattered and impermanent. By 1200 they had become much more concentrated and enduring. Although this phenomenon occurred in all regions, settlement concentration and hierarchy differed widely. In this paper, we seek to

45 better understand how the processes influencing the concentration and hierarchy of rural settlement patterns might act in different ways. To do this, we build an agent-based model entitled SimFeodal that simulates their combined effects on the relocation of peasant households from 800 to 1200 . Our research objective is to determine how certain social and demographic variables interacted with the processes modelled to produce different regional settlement patterns. We simulate a series of 15 scenarios with SimFeodal on the basis of data available for the diocese of Tours (France). The results show that demographic growth was not the primary cause of increasing settlement hierarchy. However, introducing demographic growth into the simulated scenarios yields simulation results that better match the empirical data. Interestingly, the size of villages and small towns in 800, the proportion of peasant households relocating only locally and the power of village communities do not seem to influence concentration and hierarchy in the simulated patterns.
\end{abstract}

\section{Keywords}

Agent-based model; settlement hierarchy; demographic growth; intra-regional migrations; Middle Ages

\section{Introduction}

Around the year $800 \mathrm{CE}$, the Carolingian Empire reached its greatest territorial extent, covering a large swathe of Europe from the Ebro to the Elbe. Regionally, settlement patterns were a mix of small

65 scattered villages (loose clusters of a few houses) and isolated farmsteads. Villages and farms were impermanent and their location often shifted by a few tens of metres to several hundred metres every one or two centuries. In this period, towns were civitas capitals inherited from Antiquity. Some served a central function as episcopal sees but their economic and administrative role was minor.

By about the year $1200 \mathrm{CE}$, the piecemeal dismantling of the Carolingian Empire was complete. Regional settlement patterns were by then composed of more permanent population clusters around castles and churches. Population clusters (hamlets, villages and towns) were more numerous and more stable than in $800 \mathrm{CE}$. The towns that had existed in $800 \mathrm{CE}$ had grown much larger having developed productive and commercial activities and new nuclei had formed around suburban monasteries. Many small towns had emerged around castles or rural monasteries ringed by their own precinct walls

75 (Gauthiez et al. 2003).

Thus what had been a dispersed regional settlement pattern in $800 \mathrm{CE}$ had become much more concentrated and hierarchical by 1200 CE. This phenomenon occurred throughout North-Western Europe but the degree of concentration and hierarchy differed markedly. A combination of several processes can explain this major transition. 
- The dismantling of the Carolingian Empire and the dissipation of power induced struggles among lords and so an upsurge of violence. This produced a spate of castle-building and an increased need of protection for peasant households.

- The militarisation of society heightened the lords' needs for both money and fighting men. This initiated the "feudal revolution" of the eleventh century, when ever lesser lords appropriated various administrative, fiscal and judicial rights for themselves and their vassals with an ensuing surge in usage fees and rents paid by peasant households to their lords.

- Peasant households organised themselves into village communities so as to boost their productivity and counterbalance the power of their lords.

- Religious control over society strengthened considerably, especially as a result of the Gregorian Reform. This led to the development of pastoral care, more parish churches and higher usage fees and rents paid by peasant households to the Church.

In this paper, we seek to better understand the different ways in which these processes influenced the concentration and hierarchy of rural settlement patterns. To this end, we construct an agent-based model entitled SimFeodal that simulates the combined effects of these processes on the relocation of

95 peasant households from 800 to 1200. Using SimFeodal, we attempt to determine how certain social and demographic variables (e.g. the population size in 800 , the intensity of demographic growth or the power of village communities) interact with the processes modelled to produce different regional settlement patterns for the period under consideration.

100 A growing body of literature shows that agent-based simulation may help archaeologists to generate possible pasts and potentially compare and contrast them with patterns observed in empirical data recovered from the material record (Cegielski \& Rogers 2016; Davies \& Romanowska 2018). Agent-based simulation is employed to approach various research topics such as the dynamics of complex socio-ecological systems (Kohler et al. 2012; Rogers et al. 2012; Barton et al. 2012), the 105 dynamics of hominin dispersal in prehistoric times (Wren et al. 2014; Hölzchen et al. 2016), the rise of social complexity (Rouse \& Weeks 2011; Crabtree et al. 2017), or even processes of cultural change (Dean et al. 2000; del Castillo et al. 2014). Crema (2018) reports that agent-based simulations can be used either to support theory building and explore the implications of one or more behavioural assumptions, or to test hypotheses in a particular historical-geographic context,

110 with outputs that are directly comparable to observed data. Crema (2018) quoting Lake (2014) specifies that very often the two objectives coexist in the same simulation, especially in the case of empirically grounded models designed to emulate a specific historical window and from this to explore more general aspects of human behaviour such as the emergence of hierarchical societies (Kohler et al. 2012). This is precisely the case of SimFeodal, with the general aspects of human 115 behaviour considered here being the denser criss-crossing of space with parishes and castles, and the emergence of enduring hierarchical regional settlement patterns. 


\section{Description of SimFeodal}

SimFeodal simulates the emergence of enduring population clusters around castles and churches. Over time, population clusters (hamlets, villages, small towns) become more numerous although some of them disappear; many clusters grow in population (i.e. the number of peasant households increases) but some clusters grow more than others.

Our simulation begins in the year 800 and ends in 1200. The latter date is not distinctive but was chosen on the basis of two criteria. First, a simulation must make allowance for all the important events occurring in the period under consideration (piecemeal dismantling of the Carolingian Empire, Gregorian Reform, establishment of the feudal system, etc.). Second, the time span has to be long enough to determine whether or not the dynamics simulated are lasting features. Each step in the simulation represents 20 years, which corresponds more or less to an average generation in the period in question. Thus our simulation comprises 18 steps.

The SimFeodal agent-based model has been created using the GAMA platform (Grignard et al. 2013). In this paper, we provide an overall description of the model while a detailed description can be found in the GitHub repository [https://github.com/SimFeodal].

\subsection{Entities of the model}

SimFeodal is designed to simulate the impact of social and political changes on regional settlement patterns but not to simulate the changing social and political processes themselves. Consequently, only entities playing a direct spatial role have been introduced into the model (Table 1). By contrast,

135 we omit entities with no direct influence on the spatial distribution of population (e.g. merchants) or that are not present regionally (e.g. central authority (king or emperor) and the Holy See) during the period. The entities modelled are abstract representations of real-world entities. Apart from the overlords, they are all spatial in nature and so have a geometry and geographical coordinates. Agents in SimFeodal are named "active entities" in Table 1.

Table 1. Entities in the SimFeodal model.

\begin{tabular}{|c|c|c|c|}
\hline Name & Categories & Activity & Level \\
\hline \multirow{2}{*}{ Peasant households } & Relocating locally and long distance & \multirow{2}{*}{ Active } & \multirow{2}{*}{ Micro-geographic } \\
\hline & Relocating locally only * & & \\
\hline \multirow{2}{*}{ Lords } & Overlords (princes, counts) & \multirow{2}{*}{ Active } & \multirow{2}{*}{ Micro-geographic } \\
\hline & Small lords (castellans, knights, etc.) & & \\
\hline \multirow{3}{*}{ Tax areas } & Rents & \multirow{3}{*}{ Passive } & \multirow{3}{*}{ Micro-geographic } \\
\hline & High justice rights & & \\
\hline & Other rights & & \\
\hline \multirow{3}{*}{ Focal points } & Parish churches & Active & \multirow{3}{*}{ Micro-geographic } \\
\hline & Castles & Passive & \\
\hline & Village communities & Passive & \\
\hline Population clusters & & Passive & Meso-geographic \\
\hline Poles & & Passive & Meso-geographic \\
\hline
\end{tabular}

* Peasant households so dependent on their lord that they cannot leave his estates (serfs, slaves). 
Each peasant household is represented by a point corresponding to the head of its agricultural holding.

145 Peasant households are an abstraction in that they are permanent throughout a simulation. Their activity consists in their potential relocation from one generation to the next.

Lords represent the functions they exercise but not the persons themselves. Secular lords and ecclesiastical lords are not differentiated. They can take on new rights (through the creation of tax areas) and build castles if powerful enough. Small lords are located within the modelled region and

150 their spatial range of action is narrow. By contrast, overlords are not located and can act (i.e. create a castle or collect taxes) in any location in the region modelled.

Tax areas are circular spatial entities held by the lord who creates them. Any of three types of fees can be collected through tax areas, one type per tax area: rents, high justice rights and other rights (usage rights).

155 Parish churches can modify the boundaries of their catchment area and initiate the building of new churches in their neighbourhood. They are abstractions because the decisions were actually taken by the secular or ecclesiastical lords who hold the parishes.

Some entities (poles and population clusters) come under a meso-geographic level as they are defined as the aggregation of micro-geographic entities. A pole is a cluster of neighbouring focal points

160 (parish churches, castles, village communities). In some cases, it can be made up of only one focal point. A population cluster is a cluster of several neighbouring peasant households and focal points. These meso-geographic entities have no capacity for action but their influence on the behaviour of micro-geographic agents (peasant households, lords and parish churches) is crucial.

\section{2.2 Modelled processes: overall description}

Peasant households can move (i.e. relocate) at each simulation step. Their moves are to a nearby pole or, less often, to a more distant location. Their successive relocations can lead to the creation or the disappearance of population clusters. Village communities can emerge in the clusters. Parish churches become more numerous and modify their catchment areas in order to serve as many peasant

170 households as possible. The number of lords also grows dramatically and their hierarchy increases, which corresponds to the elaboration and extension of the feudal system. Lords build castles and collect taxes from peasant households. Over the course of time, lords take on new rights and create new tax areas that may totally or partially overlie existing tax areas.

\section{$175 \quad 2.3$ Rules of behaviour for lords}

At the beginning of a simulation, small lords collect rents from all peasant households located within their tax area. Overlords collect rents from the peasant households located outside the tax areas of small lords. Because there are few small lords at the beginning of a simulation, most peasant households pay rent to an overlord.

180 New small lords appear in the course of a simulation. They are located within a population cluster chosen at random. Some of them get a tax area for rents in which they can collect rents from 5 to $25 \%$ only of the peasant households.

In the course of a simulation, all lords can also create tax areas for other rights. Small lords collect fees from 5 to $25 \%$ only of the peasant households in their tax areas whereas overlords collect fees

185 from all peasant households in their tax areas.

Another mechanism is the creation of tax areas for high justice rights which applies exclusively to overlords before the year 1000. From this date on, some small lords who possess a castle (i.e. castellans) can create a tax area for high justice rights around their castle. 
The amount of fees collected from peasant households by each lord determines his power which increases to varying degrees in the course of a simulation. Once a lord is powerful enough, he can build one or more castles. In the course of a simulation, overlords lose many of the rents they initially collected from peasant households located outside tax areas but they gain rents collected within tax areas linked to the castles they have built.

Last but not least, lords can pass on some of their rights to other lords. Similarly, a lord can pass the custody of his castle to another lord, who then becomes a castellan. Through this process of transfer of rights, some small lords can grow very powerful. Thus they may build castles and gain high justice rights. Mechanisms representing lords' gains in power in SimFeodal are simple. In particular, the creation of vassalage networks is not modelled.

\subsection{Rules of behaviour for parish churches}

A Voronoi tessellation is used to delimit the catchment area of each parish church. On this basis, the construction of a new parish church or the allocation of parochial rights to a single church depends locally on the number of peasant households within the catchment area of the existing parish church and the number of peasant households that are too far from the parish church (Figure 1). Each time a 205 new parish church appears, a Voronoi tessellation is applied in order to update the catchment areas of all churches.

Figure 1. Mechanisms leading to the creation of new parishes.

State t: two parishes

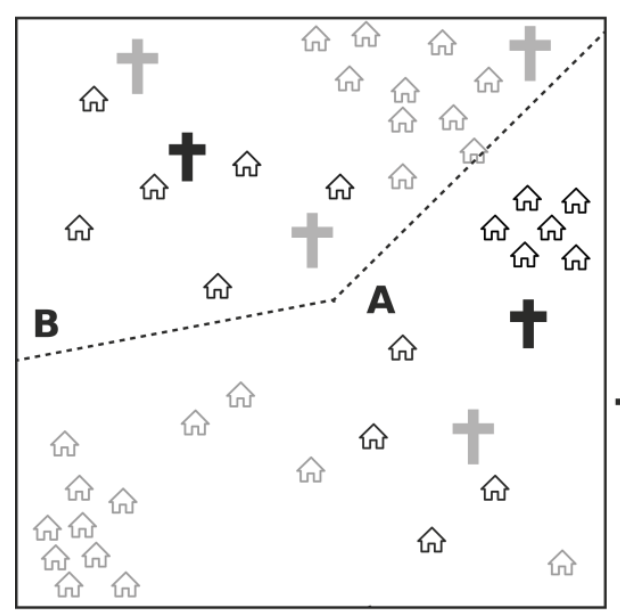

Peasant household too far from parish church

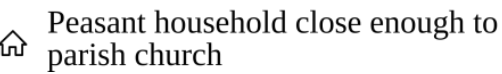

In parish A: construction of a new parish church.

In parish B, allocation of parochial rights to an existing church.
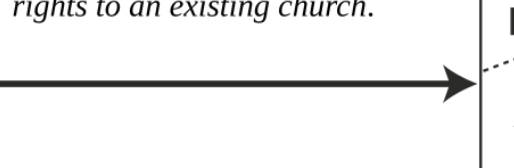

Parish church

Church without parochial rights

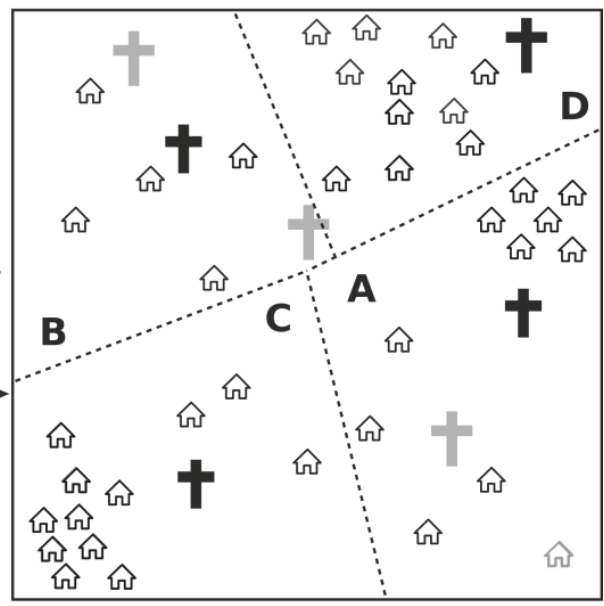

State $t+1$ : four parishes

A Parish: name and boundaries

\subsection{Rules of behaviour for peasant households}

The relocation of a peasant household depends on both its dissatisfaction with respect to its current 215 location ("push” factor) and the attractiveness of other possible locations ("pull” factor) (Figure 2). This distinction between "push" and "pull” factors is classically found in residential migration models (Ben-Akiva \& de Palma 1986; Pellegrini \& Fotheringham 2002). If a peasant household is satisfied with its current location, it can still move if another location is especially attractive. 
Contrarily, if a peasant household is highly dissatisfied with its current location, it can still stay when no other location is especially attractive. Four variables are involved in the evaluation of the overall dissatisfaction level of a peasant household:

- the ease of fulfilling religious obligations, which varies with the distance to the closest parish church,

- the satisfaction of the need for protection, which varies with the distance to the closest castle and the intensity of the need for protection,

- the satisfaction of material needs, which varies with the amount of fees paid to the lords and the power of the village communities,

- the fact that a peasant household belongs to a village community or not.

230 Figure 2. Relocation process of a peasant household.

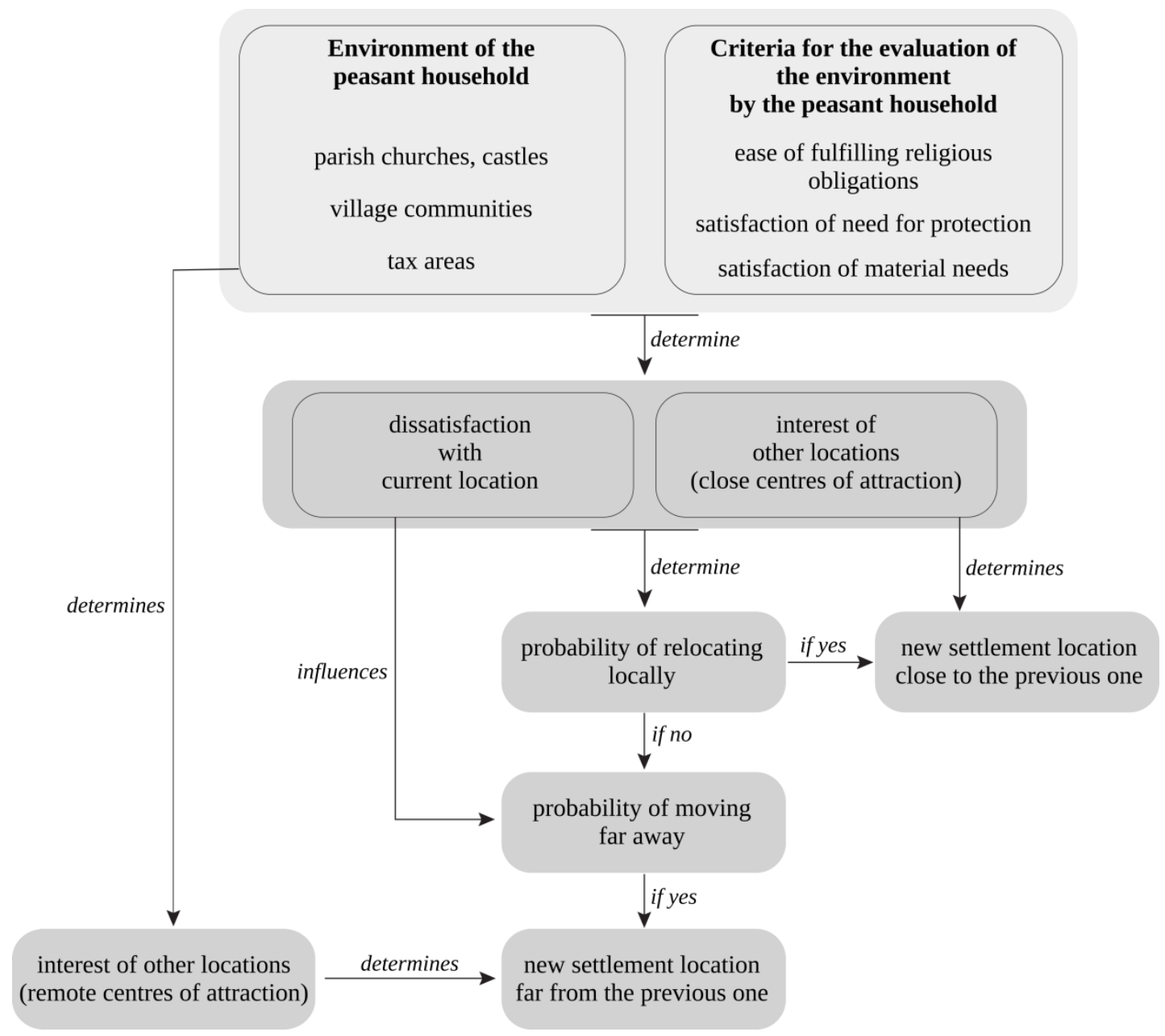

A variable number of peasant households disappear and appear in the course of simulation. Thus we represent the fact that some peasant households can enter or exit the region under study, or have no descendants. Those that appear are placed in a population cluster chosen by a probabilistic lottery weighted by the number of peasant households in each cluster.

Although possible variations in agricultural productivity between 800 and 1200 might be expected to have a significant influence on how the material needs of peasant households were met, food resources do not figure as an independent variable in the model. Among short-term variations, crop 
240 failures due to bad weather were frequent, and they occurred every six or seven years in average during the $8^{\text {th }}$ and $9^{\text {th }}$ centuries. They often resulted in famines, but they seem to have become rare, or even to have disappeared, after the $9^{\text {th }}$ century (Devroey 2009). Given the time span covered by a single simulation step in SimFeodal (20 years) and the time span of a full simulation (400 years), annual variations in agricultural productivity did not seem relevant to the model. In the long-term,

245 from 800 to 1200, the question of agricultural yields is difficult to address because of the scarcity of quantifiable data during this period. The problem of agricultural intensification is closely related to that of demographic growth, and the two are presented as alternative primary explanatory factors in most studies of socio-economic change. While historians and archaeologists adopting a neoMalthusian approach consider that population growth is limited by the availability of food resources,

250 those favouring Boserupian theory believe conversely that population pressure brings about the intensification of food production, but the two factors are difficult to disentangle for past societies (Chamberlain 2006, 4-5). While there is no doubt that both agricultural production and population size increased significantly between 800 and 1200, there have been many debates about the timeline and the magnitude of this economic and demographic growth. The renewal of archaeological 255 documentation over the past 30 years and the development of environmental studies have called into question earlier assumptions relying on the historical record. Because documentary evidence is poorly preserved until the $11^{\text {th }}$ century (Geary 1994) and because archaeological evidence for early medieval settlements is so much less conspicuous than the material remains from Antiquity or from later Middle Ages, it was long assumed that both population and economy were drastically downsized during the

260 Post-Roman centuries, and that this regression was followed by a dramatic surge of both during the $11^{\text {th }}$ century, when there is a spectacular increase in the surviving historical records (Fossier 1982). The development of large-scale excavations and surveys through contract archaeology revealed an unexpected density of early medieval settlements, most of them short-lived (a few centuries, sometimes less), some featuring commodities (fine ware, metal-work...) suggesting a well-to-do

265 population with far-reaching connections. The discovery of numerous storage-pits in these settlements, and the increase in storage capacity in the $9^{\text {th }}$ and $10^{\text {th }}$ century, points to the stocking of larger agricultural surpluses, even if it is seldom possible to give quantified estimates (Vigil-Escalera, 2013; Lauwers \& Schneider 2020). These findings, together with a reconsideration of the scarce historical record of the period, have entailed a reappraisal of the previous pessimistic view of the

270 period. Current work suggests instead that the progressive growth of medieval agricultural productivity can be traced back as early as the $8^{\text {th }}$ or $9^{\text {th }}$ century (Devroey 2003; Toubert 2004; Leturcq \& Mazel 2021).

\subsection{Identification of population clusters}

275 A population cluster is defined as a set of at least five peasant households. It gathers peasant households and focal points (parish churches, castles, and village communities) distant from one another of less than $100 \mathrm{~m}$. Population clusters are identified and delineated at the end of each simulation step according to the following process. First, the convex hull of each cluster is created and then enlarged by a given distance (100 m by default). Enlarged clusters that intersect each others

280 are then merged and the final list of population clusters is thus obtained. Peasant households that do not belong to a population cluster are considered as being dispersed.

\subsection{Comments}

The dynamics modelled in SimFeodal refer to changes in the social positions of the agents (e.g. 285 increase in the rights held by some lords) or their spatial positions (e.g. relocations of peasant households). Agents interact through spatial neighbourhoods. For instance, the interactions between lords and peasant households occur through the tax areas: arrivals and departures of peasant 
households in the territory controlled by a lord modify his power and, consequently, his chances of building a castle.

Several scholars have discussed the trade-offs between the realism of models and their generality, and their implications for archaeological applications (Lake 2015). Classically, the distinction is made between KISS (Keep It Simple Stupid) models that simulate the emergence of stylised facts on the basis of very simple agent behaviours which may be very far removed from reality (Axelrod

295 1997), and KIDS (Keep It Descriptive Stupid) models that focus more on empirical mechanisms and represent as simply as possible agent behaviours observed in the real world (Edmonds \& Moss 2005). Mechanisms in SimFeodal are hardly realistic because the behaviours of the agents (peasant households, lords and parishes from 800 to 1200) are not fully known. Consequently, SimFeodal combines both KISS and KIDS mechanisms as recommended by Edmonds \& Moss (2005). The

300 case of the catchment areas of parish churches is illustrative. Catchment areas are represented by Thiessen polygons resulting from Voronoi tessellation. Such a mechanism does not correspond to the empirical reality around 800 because peasant households might attend one or more churches once or twice a year and the churches attended could be located anywhere, close to or far from the location of the household's farm, and might or might not have parochial rights. So the Voronoi tessellation for

305 this period is a KISS mechanism. Around 1200, by contrast, peasant households fulfilled their (numerous) religious obligations in the closest parish church. Thus Thiessen polygons provide quite a good representation of the catchment areas of parish churches that have been found empirically (Zadora-Rio 2008) and it is a KIDS mechanism.

310 In agent-based modelling, it is possible to distinguish weak emergence - where the macroscopic structures resulting from microscopic behaviours can be observed by an external observer identifying a particular regularity in the process observed - from strong emergence - where the microscopic entities themselves observe the macroscopic structures they have produced and adapt their behaviours accordingly (Livet et al. 2010). In SimFeodal, emergence is strong because peasant households

315 consider the drawing power of poles of attraction: when they are ready to move, they "observe" (compare) the attractiveness of poles (either locally or region-wide) in order to choose their new location. In general, social systems are characterised by strong emergence. Individuals participate in creating collective references that refer to the social group or to the place to which they belong (weak emergence). In turn, the adoption (or not) of these collective references by the group or the individual

320 influences its behaviour (strong emergence) (Tannier et al. 2016). In SimFeodal, peasant household's knowledge of the drawing power of centres of attraction is a collective reference in the sense that it is the same for all peasant households in the region modelled. This collective reference influences in turn the individual behaviour of each peasant household. It evolves in the course of simulation. It does not directly influence the behaviours of the lords and the parishes but it arises from their actions,

325 namely the creation of castles and new parishes. In turn, those creations depend on the location choices of peasant households.

\section{Setting default values for SimFeodal parameters on the basis of the diocese of Tours (France)}

Here we look to fix a basic set of parameter values with which simulation results approach a series of quantitative and qualitative objectives. The scenario simulated with this basic set of parameter values must represent a plausible past, which should be as realistic as possible. In no case, however, 335 do we expect to reproduce the real past situation, for two main reasons. First, SimFeodal is a purely exploratory model: many aspects of the system being modelled are not known. Consequently, simulations should be used as an exploration of intertwined cause-and-effect processes. They 
should help to facilitate understanding of past changes but they cannot reproduce the past that really occurred. Second, even if the entities of the model correspond to real-world entities, even if the 340 rules of behaviour for the agents are realistic, and even if the simulation results are close to the targeted objectives, this does not mean the modelled scenario is "true"; it only proves it is in principle plausible (Varenne 2010). Indeed, it is possible to simulate a given socio-spatial configuration at a macroscopic level from various sets of microscopic mechanisms, as with equifinality problems (von Bertalanffy 1968; Premo 2010). Thus the capability of a model to 345 reproduce observed facts does not imply that this model is "true" or valid, especially in the case of agent-based models (Amblard et al. 2007), and a fortiori in the case of socio-spatial systems characterised by a strong under-determination between processes and morphological laws (Varenne 2016). Knowing this, the basic scenario corresponding to the default values of parameters for SimFeodal is considered only as a benchmark for defining other exploratory scenarios in which we

350 vary the value of unknown parameters, especially the total number of peasant households in 800 , the growth rate of this number, and the proportion of peasant households relocating only locally (serfs, slaves) (see section 4).

In order to set default values of parameters for SimFeodal, our reference case study is the diocese of 355 Tours whose settlement dynamics during the Middles Ages has been the subject of historical and archaeological research over the past 30 years (Galinié \& Audinet 1992; Joly 1997; Lorans 1996; Maillard 1998; Nissen Jaubert 2012; Nissen 2014; Zadora-Rio 2008, 2009, 2014). Archaeological evidence from excavations and field surveys has revealed many population clusters (hamlets, villages) in 800 which were short-lived and shifted across the landscape. They became progressively

360 more permanent, and most of those that existed in 1200 have survived to this day. The towns that existed in 800 were enlarged by the addition of new boroughs in the $11^{\text {th }}$ and $12^{\text {th }}$ centuries, and small new towns emerged around castles or rural monasteries.

In order to perform relevant simulations with SimFeodal, the study area has to be large enough to enable us to observe the increasing coverage of space with parishes and castles from 800 to 1200 . As

365 the former diocese of Tours extended over $5508.4 \mathrm{~km}^{2}$, the area of the province of Touraine in the eighteenth-nineteenth century was $7150 \mathrm{~km}^{2}$, and the present-day department of Indre-et-Loire covers $6126.7 \mathrm{~km}^{2}$, the chosen study area is a square with $79 \mathrm{~km}$ sides $\left(6241 \mathrm{~km}^{2}\right)$. The total width of the simulated region is $80 \mathrm{~km}$ because a buffer zone of $1 \mathrm{~km}$ is removed from the calculation in order to avoid boundary effects. The space is isotropic, without any natural features (relief, rivers, coastlines,

370 etc.). The assumption here is that natural features only influence the spatial distribution of settlement sites in a region but not the global density of sites or their global hierarchy. In addition, no major city, namely here the city of Tours, is represented. Indeed, the attractiveness of a central city for surrounding rural areas and intra-urban location processes is not modelled in SimFeodal.

375 Distinctive characteristics of the diocese of Tours in 800 are introduced via specific values of input parameters, in particular the number of population clusters and parish churches, and the existence of two almost equally powerful overlords (namely, the Counts of Anjou and Blois) (Table 2). The number of castles is set to zero because only lineage castles are represented in SimFeodal (their construction begins in the mid-tenth century) but not the large collective enclosures (strongholds, 380 castra) that existed in 800 . The number of peasant households in each village (about 10) has been extrapolated from archaeological data available for the diocese of Tours (Nissen 2014) and other regions (Zadora-Rio 2009), but it is largely conjectural. No early medieval settlements have been entirely excavated in Touraine, and within the limits of the excavated areas, it was seldom possible to recognize more than 5 or 6 houseplots, rounded up to 10 to make allowance for the unexcavated 385 part of the sites (Nissen 2014). It must be reminded that it is far from straightforward to infer the number of contemporary households from the number of excavated buildings within a settlement. It 
is also hardly possible to determine if the remains of two settlements dated to the same general period are strictly contemporary: the trouble with archaeological evidence is that it does not allow us to know for sure whether we are dealing with a large population, or a mobile one (Bintliff \& Sbonias 1999;

390 Francovitch, Patterson \& Barker 2000; Gandini, Favory \& Nuninger 2012). Archaeological evidence does not produce direct information on demographic change, but only proxy-data, generally providing only qualitative or semi-quantitative information about population trends (Chapman 1999). Concerning the small towns in 800 , the setting value of 30 peasant households is even more hypothetical: the existence of early medieval small towns is known both through the historical and 395 the archaeological records, but we do not have any data about the number of households they included. Finally, with all these setting values, we assume implicitly that the proportion of dispersed population in 800 is extremely high: $95 \%$ of peasant households are located outside any village or town.

400 In the current state of knowledge, considering the small sample represented by the areas in which excavations and systematic surveys were carried out, and the limited use of archaeological proxies to produce demographic data, we could not rely on archaeological evidence to produce the population estimates that were needed in SimFeodal, and we turned instead to the historical record. In general, and in the region of Touraine in particular, demographic data are only recorded from the eighteenth 405 century onwards. One exception is the diocese of Chartres, which borders on the diocese of Tours and for which a thirteenth-century Pouillé (1250-1272) provides the number of parrochiani (heads of households) for each parish in the diocese. On the basis of this Pouillé, Chédeville (1973) determined the percentage of population growth between the mid-thirteenth and early nineteenth centuries $(+17 \%)$. Thus, we opted to consider the number of inhabitants in the region of Touraine in the early 410 nineteenth century to which we applied the percentage of population growth calculated by Chédeville (1973) for the diocese of Chartres. At the beginning of the nineteenth century, the province of Touraine had 253,589 inhabitants excluding the city of Tours, which had 21,703 inhabitants (Le Mée 1989). Applying the differential percentage of $-17 \%$ gives 216,743 inhabitants in the mid-thirteenth century, which corresponds to around 48,165 peasant households. The area of the province of 415 Touraine in the eighteenth-nineteenth century was $7150 \mathrm{~km}^{2}$, which is noticeably larger than the area of the simulated region $\left(6241 \mathrm{~km}^{2}\right)$. Adjusting for the smaller size of the diocese of Tours and assuming a similar population density reduces the estimated number of households to 41,900. Finally, we opted to round the number down to 40,000 households in 1200 . By default, we did not make any assumption about demographic change between 800 and 1200, in spite of the fact that population 420 growth is often considered as a primary explanatory factor for the increasing hierarchy of regional settlement systems in the period under consideration (Fossier 1982). The default value for the number of peasant households in 800 (Table 2) is thus the same as the estimated number in 1200, i. e. 40.000. This is a very strong hypothesis, supported by the lack of quantitative data (see above), and we seek to test it with SimFeodal in the next section of the paper. 
Table 2. Default values of input parameters set for the Tours diocese in $800 .^{+}$: speculative estimate. *: estimate based on the sources available for the diocese of Tours (Zadora-Rio 2008).

\begin{tabular}{|c|c|}
\hline Title & Value \\
\hline \multicolumn{2}{|l|}{ Peasant households } \\
\hline Number of peasant households in the modelled region & $40000^{+}$ \\
\hline \multicolumn{2}{|l|}{ Population clusters } \\
\hline Number of Roman small towns & 8* \\
\hline Number of peasant households within each small town & $30^{+}$ \\
\hline Number of villages & $20^{+}$ \\
\hline Number of peasant households within each village & $10^{+}$ \\
\hline \multicolumn{2}{|l|}{ Lords } \\
\hline Number of overlords & $2 *$ \\
\hline Relative power of the overlords (sum equal to 1) & $\begin{array}{l}0.5 \\
0.5\end{array}$ \\
\hline Number of small lords & $18^{+}$ \\
\hline \multicolumn{2}{|l|}{ Churches } \\
\hline Total number of churches & $150 *$ \\
\hline Number of parish churches & $50 *$ \\
\hline \multicolumn{2}{|l|}{ Castles } \\
\hline Number of castles & $0 *$ \\
\hline
\end{tabular}

430

Contextual parameters corresponding to historical postulates are listed in Table 3. Many of them represent the major political and social changes during the time period in question (Figure 3 ). Some contextual parameters are specific to the region under study, e.g. the power of village communities, which is considered to be rather low in the diocese of Tours (Bourin \& Durand 1984). 
Table 3. Values of contextual parameters set for the diocese of Tours.

\begin{tabular}{|c|c|}
\hline Title & Value \\
\hline \multicolumn{2}{|l|}{ Peasant households } \\
\hline Growth rate of the number of peasant households at each simulation step & $0 \%$ \\
\hline $\begin{array}{l}\text { Percentage of peasant households that appear and disappear at each } \\
\text { simulation step }\end{array}$ & $0.05(5 \%)$ \\
\hline $\begin{array}{l}\text { Proportion of peasant households that can only relocate locally (serfs, } \\
\text { slaves) }\end{array}$ & $0.2(20 \%)$ \\
\hline Intensity of the need of protection & $\begin{array}{l}0 \text { between } 800 \text { and } 940 \\
0.2 \text { in } 960 \\
0.4 \text { in } 980, \\
0.6 \text { in } 1000 \\
0.8 \text { in } 1020 \\
1 \text { since } 1040\end{array}$ \\
\hline $\begin{array}{l}\text { Distance to the closest parish church beyond which a peasant household } \\
\text { is not fully satisfied. }\end{array}$ & $\begin{array}{l}5 \mathrm{~km} \text { before } 950 \\
3 \mathrm{~km} \text { from } 950 \text { to } 1050 \\
1.5 \mathrm{~km} \text { after } 1050\end{array}$ \\
\hline $\begin{array}{l}\text { Distance to the closest parish church beyond which a peasant household } \\
\text { is absolutely dissatisfied. }\end{array}$ & $\begin{array}{l}25 \mathrm{~km} \text { before } 950 \\
10 \mathrm{~km} \text { from } 950 \text { to } 1050 \\
5 \mathrm{~km} \text { after } 1050\end{array}$ \\
\hline $\begin{array}{l}\text { Distance to the closest castle beyond which a peasant household is not } \\
\text { fully satisfied. }\end{array}$ & $1.5 \mathrm{~km}$ \\
\hline $\begin{array}{l}\text { Distance to the closest castle beyond which a peasant household is } \\
\text { absolutely dissatisfied. }\end{array}$ & $5 \mathrm{~km}$ \\
\hline
\end{tabular}

\begin{tabular}{|l|l|l|}
\hline Population clusters & $\begin{array}{l}0.2 \text { until } 1040 \\
0.3 \text { in } 1060 \text { and } 1080 \\
0.4 \text { in } 1100,1120 \text { and } 1140 \\
0.5 \text { in } 1160,1180 \text { and } 1200\end{array}$ \\
\hline Power of village communities in the modelled region & 0.2 \\
\hline $\begin{array}{l}\text { For each population cluster, probability that a village community is set } \\
\text { up as an institution at each step of simulation }\end{array}$ & 0.2 \\
\hline
\end{tabular}

\begin{tabular}{|l|l|l|}
\hline Lords & 200 \\
\hline $\begin{array}{l}\text { Targeted total number of lords (overlords and other lords) at the end of a } \\
\text { simulation }\end{array}$ & $\begin{array}{l}0 \text { before } 900 \\
0 \text { between } 900 \text { and } 980 \\
\text { since } 1000\end{array}$ \\
\hline $\begin{array}{l}\text { Probability of an overlord gaining high justice rights at each simulation } \\
\text { step }\end{array}$ & $\begin{array}{l}0 \text { before } 1000 \\
0.2 \text { since } 1000\end{array}$ \\
\hline $\begin{array}{l}\text { When a small lord builds a new castle, probability of creating a tax area } \\
\text { for high justice rights around this castle and all his other castles (existing } \\
\text { or future) }\end{array}$ & 880 \\
\hline \begin{tabular}{l|l} 
Date from which lords begin to pass rights on to their vassals \\
Date from which lords can give castles to their vassals
\end{tabular} & 940 \\
\hline Castles & from 940 to 1040 included \\
\hline Date from which castles can be built by lords & 960 \\
\hline Time period during which castles can become major castles & \\
\hline
\end{tabular}


Figure 3. Major political and social changes between 800 and 1200 and their representation in SimFeodal.

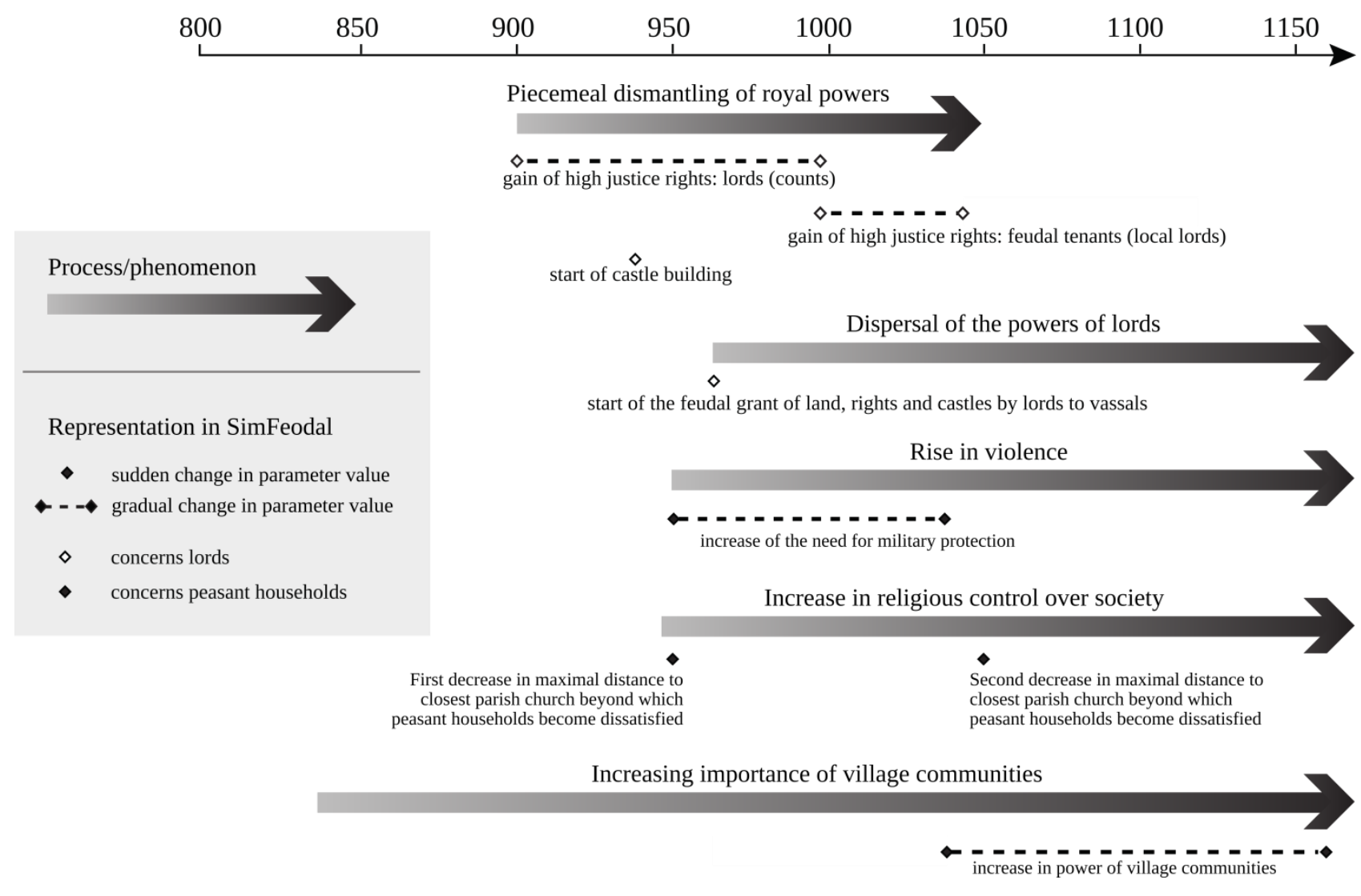

Other parameters determine the agents' endogenous behaviour (see Appendices A and B). Their values are not likely to be modified for each specific regional context but they can be modified to explore their effect on the model's dynamics. Among these parameters, technical parameters are purely mechanical parameters with no empirical basis. Parameters whose empirical values are unknown are very numerous. Some can be estimated with varying degrees of precision from archaeological records and historical texts: the distance thresholds to the closest parish church and to the closest castle, the minimum distance between castles, the probability of a castle becoming a

450 major castle when sited in or close to a pole, the maximum distance between peasant households or focal points beyond which they do not belong to the same cluster, and the minimum number of peasant households required to create a population cluster. The values of the other parameters were initially set approximately and then adjusted step by step with respect to the simulation results. A model can be calibrated against a "stylised fact" (i.e. a broad generalisation of an empirical pattern)

455 or empirical data (Davies \& Romanowska 2018). We mixed these two possibilities in calibrating SimFeodal. Two stylised facts are considered: the increasing coverage of space with parishes and castles, and the emergence of an enduring hierarchical settlement pattern around the castles and the parish churches. Over time, the number of population clusters should rise and their sizes should differ increasingly. Besides these qualitative objectives, we set some global quantitative objectives

460 that should be achieved at the end of a simulation (Table 4). The targeted total number of lords at the end of the simulation was chosen to represent a proliferation: lords are 10 times more numerous in 1200 than in 800 and four times more numerous than the final number of castles (Boussard 1962; Guillot 1972). Mechanisms determining the number of lords as well as the number of castles and major castles built at each simulation step were parameterised to necessarily reach the target values.

465 Consequently, these numbers at the end of the simulation are considered only for the internal verification of the model, i.e. checking conformity between the model specifications and the 
computer program implemented (Amblard et al. 2007). Furthermore, we assessed the consistency of agents' behaviours in the course of the simulation via the observation of step-by-step changes in a series of variables: proportion of households relocating, types of migrations undertaken by peasant households (local or distant; towards a population cluster or not, etc.), number of castles built by each type of lord, etc. The objective was to detect possible contradictions in simulated behaviours (e.g. too many or too few relocations of peasant households or illogical alternation of rises and falls in the value of a variable).

475 Table 4. Targeted quantitative objectives set to calibrate the model.

\begin{tabular}{|r|r|}
\hline \multicolumn{1}{|c|}{ Variable } & Value expected in 1200 \\
\hline Number of population clusters & {$[200-250]$} \\
\hline Number of castles & $50^{*}$ \\
\hline Number of major castles & {$[10 ; 15]^{*}$} \\
\hline Number of parishes & {$[200 ; 300]^{* *}$} \\
\hline Number of lords & 200 \\
\hline
\end{tabular}

* Sources: (Zadora-Rio 2014-4; Zadora-Rio 2014-5).

** Source: (Zadora-Rio 2008, p. 31).

480 Table 5. Values of variables in 1200 obtained by simulation with the basic parameter configuration of SimFeodal (parameter default values).

\begin{tabular}{|r|r|r|r|r|}
\hline \multicolumn{1}{|c|}{ Variable } & Mean & Median & 1st quartile & 3rd quartile \\
\hline Number of population clusters & 249 & 250 & 243 & 253 \\
\hline Number of castles & 50 & 49 & 47 & 54 \\
\hline Number of major castles & 16 & 16 & 16 & 18 \\
\hline Number of parishes & 340 & 338 & 333 & 348 \\
\hline Number of lords & 202 & 204 & 196 & 208 \\
\hline
\end{tabular}

Figure 4. Change in the number of population clusters over time (mean and 1st and 3rd quartiles). Results obtained with the basic parameter configuration (parameter default values).

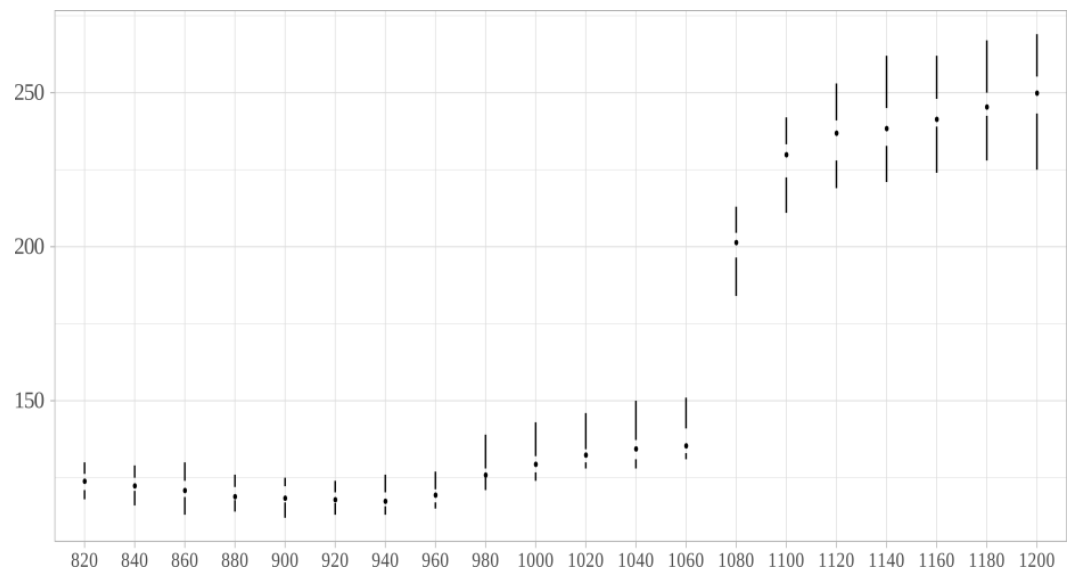

Figure 5. Change in the proportion of dispersed households over time (mean and 1st and 3rd quartiles). Results obtained with the basic parameter configuration (parameter default values). 


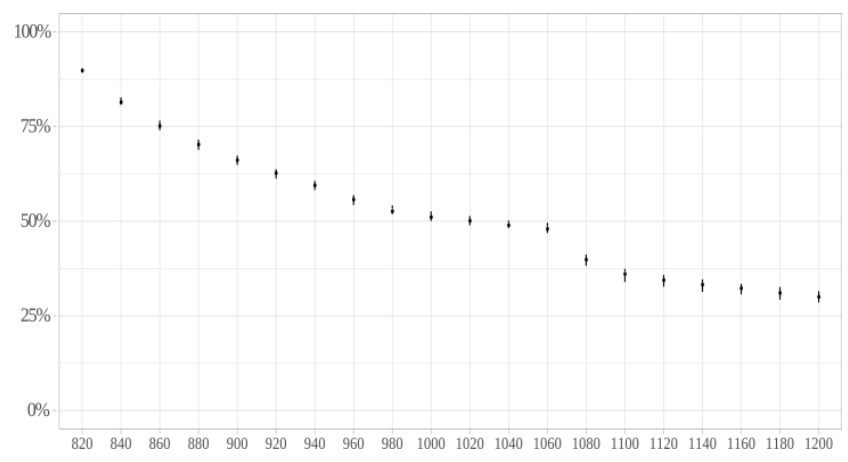

490 Figure 6. Rank-size distributions of population clusters obtained with the basic parameter configuration (parameter default values) at five dates.

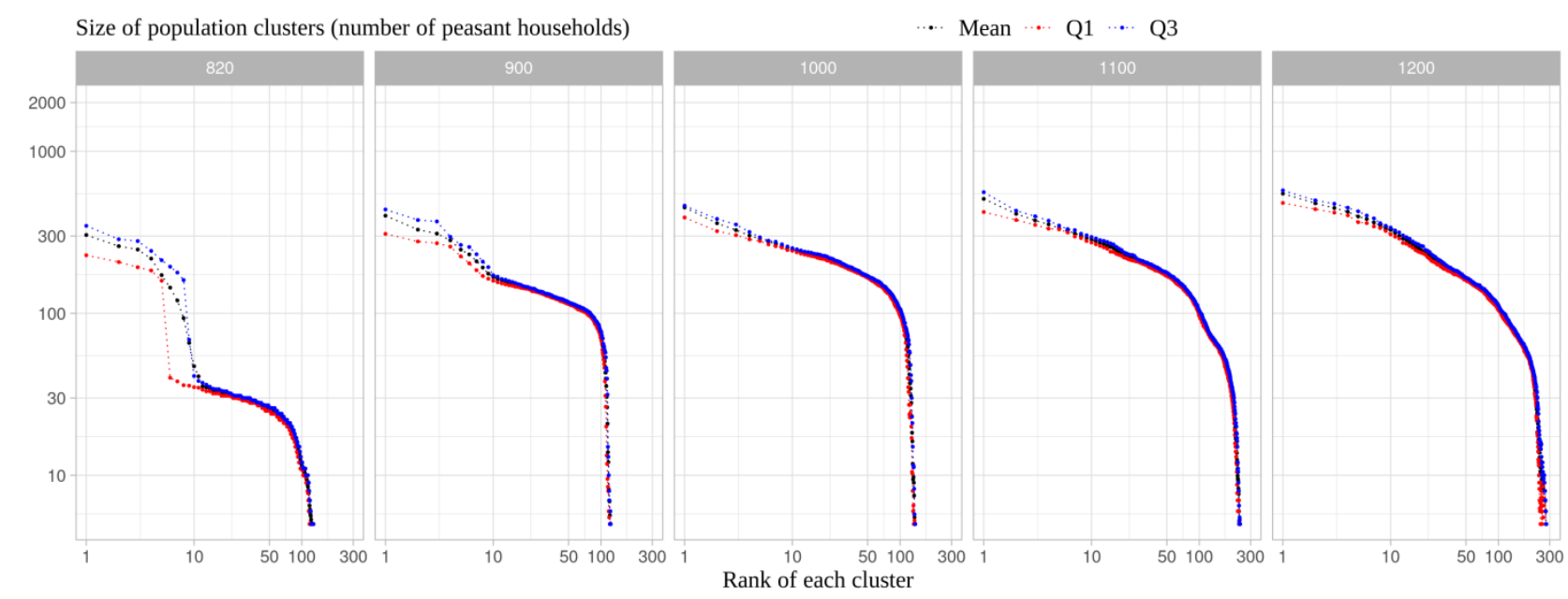

Simulation results obtained with the set of parameter default values finally chosen are presented in Table 5 and Figures 4, 5 and 6. SimFeodal involves a series of random draws, e.g. to determine whether a peasant household relocates locally or a long-distance away, or to determine whether a castle becomes a major castle, or even to determine whether a parish church is to be built within a population cluster. Consequently, for multiple simulations of the same scenario (i.e. a given set of parameter values), simulation results may vary. Considering this, the simulation results provided take into account 20 computation replications. Simulated values obtained in 1200 with the basic

500 configuration of parameters (Table 5) are close to the quantitative objectives set in Table 4. Only the number of parishes is higher. The number of population clusters starts increasing from 980. Then the increase accelerates from 1080 (Figure 4). The proportion of dispersed households falls steadily over time to $30 \%$ (Figure 5). Finally, rank-size distributions of population clusters display an increasing hierarchy of the settlement pattern (Figure 6).

From 1080-1100, the shape of the rank-size distribution becomes convex because medium and large clusters have increased more than small clusters. From 800 to 1000, the number of clusters varies little whereas cluster size changes considerably. The smallest clusters grow slightly: ranging from 5 to 25 peasant households in 820, from 5 to 100 peasant households in 900, and from 5 to 510150 peasant households in 1000 . The intermediate clusters grow considerably. The biggest clusters grow slightly but regularly from around 250 peasant households in 820 to around 400 to 550 peasant households in 1200. Their size range is wider in 1200 than in 820. Besides, we confirmed visually (on the maps displayed on a graphics monitor in the SimFeodal software application - see Appendix C) that each of the eight small towns existing in 800 becomes a medium-sized or a large 515 population cluster in the course of simulation. 


\section{Fourteen scenarios for better understanding the conditions for the emergence of enduring hierarchical settlement patterns}

This section reports on computer simulations performed to explore how varying the values of some key parameters, e. g. the number of peasant households in 800, the growth rate of this number, and the proportion of peasant households relocating only locally (serfs, slaves), can change simulated settlement patterns. The aim is to identify the factors affecting hierarchy and concentration and to understand how they act on the spatial dynamics of the settlement system. The quantitative objectives to be attained at the end of a simulation are set in Table 4. Nonetheless, we have no empirical data about the precise number of population clusters, the number of inhabitants in each cluster, and the proportion of dispersed peasant households. Considering these variables, simulation results can be for comparative purposes only but they should provide a better understanding of their explanatory factors.

We selected a series of 14 scenarios in which we varied the values of key parameters (Table 6). Each parameter is tested independently of the others knowing that the combined actions of parameters on the changes in the settlement pattern are to be explored later. As previously explained, the basic scenario corresponding to the parameter default values for SimFeodal is a benchmark for comparing all scenarios. From now on this basic scenario is referred to as "scenario $\alpha$ ". The parameters tested were chosen on the assumption that they exert a noticeable influence on the settlement pattern. Simulation results should confirm or invalidate this. The values tested are considered plausible.

Table 6. Description of the scenarios.

\begin{tabular}{|c|c|c|c|}
\hline & Parameter tested & Value(s) changed with respect to scenario $\alpha$ & $\begin{array}{c}\text { Scenario } \\
\text { title }\end{array}$ \\
\hline \multirow{7}{*}{$\begin{array}{l}\text { Input } \\
\text { parameters }\end{array}$} & \multirow{2}{*}{$\begin{array}{l}\text { Total number of peasant } \\
\text { households in } 800\end{array}$} & 30000 & A1 \\
\hline & & 50000 & A2 \\
\hline & \multirow{2}{*}{$\begin{array}{l}\text { Number of peasant } \\
\text { households in each village in } \\
800\end{array}$} & 5 & B1 \\
\hline & & 15 & B2 \\
\hline & \multirow{3}{*}{$\begin{array}{l}\text { Number of peasant } \\
\text { households in each small } \\
\text { town in } 800\end{array}$} & 20 & $\mathrm{C} 1$ \\
\hline & & 40 & $\mathrm{C} 2$ \\
\hline & & 100 & C3 \\
\hline \multirow{6}{*}{$\begin{array}{l}\text { Contextual } \\
\text { parameters }\end{array}$} & \multirow{3}{*}{$\begin{array}{l}\text { Growth rate of the number of } \\
\text { peasant households }\end{array}$} & 3.72\% starting from 20000 peasant households in 800 & D1 \\
\hline & & $12.89 \%$ starting from 4000 peasant households in 800 & D2 \\
\hline & & $14.22 \%$ starting from 4000 peasant households in 800 & D3 \\
\hline & \multirow{2}{*}{$\begin{array}{l}\text { Proportion of peasant } \\
\text { households only relocating } \\
\text { locally (serfs, slaves) }\end{array}$} & $0 \%$ & E1 \\
\hline & & $40 \%$ & E2 \\
\hline & Power of village communities & 0.25 throughout the period & $\mathrm{F}$ \\
\hline $\begin{array}{l}\text { Mechanism } \\
\text { parameter }\end{array}$ & $\begin{array}{l}\text { Radius of the local relocation } \\
\text { of peasant households }\end{array}$ & $\begin{array}{l}2.5 \mathrm{~km} \text { from } 800 \text { to } 880 ; 4 \mathrm{~km} \text { from } 900 \text { to } 980 ; 6 \mathrm{~km} \text { from } \\
1000\end{array}$ & G \\
\hline
\end{tabular}


- For scenario A, the hypothesis is that the more peasant households there are the greater the size difference of population clusters. The values tested are within the estimated uncertainty range of the default value (i.e. 40,000 peasant households).

545 - For scenarios B, the hypothesis is that larger villages in 800 produce larger population clusters over the simulation period. The values tested are within the estimated uncertainty range of the default value (i.e. villages in 800 have 10 peasant households).

- For scenarios $C$, the hypothesis is that larger small towns in 800 make for the biggest population clusters being even larger. Two of the values tested (20 and 40 peasant households in the small towns in 800) are within the estimated uncertainty range of the default value (i.e. 10 peasant households). The third value tested (100 peasant households in the small towns in 800) represents the possibility that small towns inherited from Antiquity were much larger than supposed from archaeological sources.

- For scenarios D, the hypothesis is that demographic growth is the primary cause of the increasing hierarchy of regional settlement systems during the Middle Ages. A first scenario represents a doubling of the population from 800 to 1200: starting from 20,000 peasant households in 800 , a growth rate of $3.72 \%$ yields 40,000 households in 1200 (value of scenario $\alpha$ ). The other two scenarios begin with 4000 households in 800 , a value which represents a severely downsized population. A growth rate of $12.89 \%$ was chosen so as to 560 reach 40,000 households in 1200 (value of scenario $\alpha$ ) and $14.22 \%$ was chosen so as to reach 50,000 households in 1200 (value of scenario A2).

- For scenarios E, the hypothesis is that the hierarchy of the settlement system is stronger when the proportion of peasant households relocating locally only is low. Indeed, if many peasant households can undertake long-distance migrations, this may favour their concentration in the largest population clusters because they are more attractive than the smallest clusters. The values tested for the proportion of peasant households relocating only locally ( $0 \%$ and $40 \%$ ) diverge widely from the default value (20\%) because the proportion of peasant households so highly dependent on their lord that they cannot leave his estate (serfs, slaves) is completely unknown and much debated (Corriol 2010; Feller 2007).

570 - For scenario $\mathrm{F}$, the hypothesis is that the more powerful the village communities the more concentrated the settlement system. By default, the power of village communities increases over the course of simulation. In scenario $\mathrm{F}$, the value remains low throughout the period under consideration.

- For scenario $\mathrm{G}$, the hypothesis is that increasing the radius within which peasant households may relocate locally promotes their concentration in large population clusters. In this scenario, the largest population clusters should be even larger by 1200 .

It is important to note that this experiment does not come within the scope of a sensitivity analysis, in which all uncertain parameter values are tested to understand their effects on the simulation 580 results. Moreover, the parameter values tested may or may not be close to their default values. The sensitivity analysis of the SimFeodal model has been undertaken in the PhD thesis of Cura (2020). Since the model has numerous parameters, about 70 (see Table 3, and Appendix A and B), a factorial design study of five tested values for each parameter would require to run $5^{70} \times 20$ [replications], thus about $10^{50}$ simulations. Various methods have been developed to avoid

585 such a combinatorial explosion (see e. g. Chérel et al. 2015; Montgomery 2009; Schmitt et al. 2015). All these methods require to set a few number of quantitative output assessment indexes. Yet targeted quantitative objectives set to calibrate SimFeodal are fuzzy (see Table 4). Moreover, other crucial output results are qualitative; many of them result from the observation of the global shape 
of curves (see Figures 4, 5, and 6). For those reasons, the sensitivity analysis of the SimFeodal model was based on the OFAT (One Factor at A Time) protocol.

Results of the sensitivity analysis helped us to select and parameterise the 14 scenarios tested here. The simulation results are displayed in Tables 7-9 and Figures 7-13. Prior to their analysis, we checked for the number of lords, the number of castles and the number of major castles. We also confirmed that the variability of the results was weak enough by looking at the 1st and 3rd quartiles 595 of the simulated values and their standard error for each set of 20 replications. Two variables, namely the number of population clusters and the proportion of dispersed peasant households, inform us about the concentration of the simulated settlement patterns (Table 7). The hierarchy of the simulated settlement patterns is analysed through the observation of the distribution of population clusters by class of size (Table 8 and Figure 7), the size of the four biggest population 600 clusters (Table 9) and the rank-size distribution of population clusters (Figures 8-13). In the case of Table 9, the standard errors of the mean are often very high. Consequently, only the general trend of the results can be considered but not the precise number of peasant households in each population cluster.

605 We first observe that the effect of the tested changes in parameter values is negligible in the case of the size of villages and small towns in 800 (scenarios B1, B2, C1, C2, C3), the proportion of peasant households moving only locally (scenarios E1, E2), and the power of village communities (scenario F).

610 Table 7. Mean values (and standard error of the mean in brackets) of variables in 1200 obtained by simulation for 20 computation replications of each scenario. *: number of peasant households per $\mathrm{km}^{2}$. Grey cells: variable values that differ noticeably from the values in scenario $\alpha$. Note: mechanisms determining the total number of peasant households as well as the population density were parameterised to necessarily reach the target values.

\begin{tabular}{|c|c|c|c|c|c|c|c|c|c|c|c|c|c|c|c|}
\hline & \multicolumn{15}{|c|}{ SCENARIOS } \\
\hline & $\alpha$ & A1 & A2 & B1 & B2 & C1 & C2 & C3 & D1 & D2 & D3 & E1 & E2 & $\mathbf{F}$ & G \\
\hline $\begin{array}{r}\text { Number of } \\
\text { population } \\
\text { clusters }\end{array}$ & $\begin{array}{l}249 \\
{[2.3]}\end{array}$ & $\begin{array}{l}231 \\
{[2.3]}\end{array}$ & $\begin{array}{l}262 \\
{[3.2]}\end{array}$ & $\begin{array}{l}241 \\
{[2.3]}\end{array}$ & $\begin{array}{l}245 \\
{[2.4]}\end{array}$ & $\begin{array}{l}248 \\
{[2.2]}\end{array}$ & $\begin{array}{l}248 \\
{[2.1]}\end{array}$ & $\begin{array}{l}245 \\
{[2.3]}\end{array}$ & $\begin{array}{l}226 \\
{[2.6]}\end{array}$ & $\begin{array}{l}198 \\
{[1.9]}\end{array}$ & $\begin{array}{c}213 \\
{[1.9]}\end{array}$ & $\begin{array}{l}241 \\
{[1.8]}\end{array}$ & $\begin{array}{l}246 \\
{[2.6]}\end{array}$ & $\begin{array}{l}250 \\
{[2.4]}\end{array}$ & $\begin{array}{l}217 \\
{[2.4]}\end{array}$ \\
\hline $\begin{array}{r}\text { Number of } \\
\text { parishes }\end{array}$ & $\begin{array}{l}348 \\
{[2.9]}\end{array}$ & $\begin{array}{c}302 \\
{[3.5]}\end{array}$ & $\begin{array}{l}374 \\
{[3.0]}\end{array}$ & $\begin{array}{l}340 \\
{[2.7]}\end{array}$ & $\begin{array}{l}336 \\
{[2.3]}\end{array}$ & $\begin{array}{l}337 \\
{[2.1]}\end{array}$ & $\begin{array}{c}334 \\
{[3.0]}\end{array}$ & $\begin{array}{l}338 \\
{[3.6]}\end{array}$ & $\begin{array}{c}307 \\
{[3.0]}\end{array}$ & $\begin{array}{l}252 \\
{[3.2]}\end{array}$ & $\begin{array}{l}277 \\
{[2.1]}\end{array}$ & $\begin{array}{l}336 \\
{[3.5]}\end{array}$ & $\begin{array}{c}331 \\
{[2.7]}\end{array}$ & $\begin{array}{l}345 \\
{[4.0]}\end{array}$ & $\begin{array}{l}333 \\
{[2.8]}\end{array}$ \\
\hline $\begin{array}{r}\text { Percentage } \\
\text { of } \\
\text { dispersed } \\
\text { households }\end{array}$ & $\begin{array}{c}30 \\
{[0.2]}\end{array}$ & $\begin{array}{c}32 \\
{[0.2]}\end{array}$ & $\begin{array}{c}29 \\
{[0.2]}\end{array}$ & $\begin{array}{c}31 \\
{[0.2]}\end{array}$ & $\begin{array}{c}30 \\
{[0.2]}\end{array}$ & $\begin{array}{c}30 \\
{[0.2]}\end{array}$ & $\begin{array}{c}30 \\
{[0.2]}\end{array}$ & $\begin{array}{c}30 \\
{[0.2]}\end{array}$ & $\begin{array}{c}27 \\
{[0.2]}\end{array}$ & $\begin{array}{c}21 \\
{[0.2]}\end{array}$ & $\begin{array}{c}19 \\
{[0.2]}\end{array}$ & $\begin{array}{c}28 \\
{[0.2]}\end{array}$ & $\begin{array}{c}33 \\
{[0.3]}\end{array}$ & $\begin{array}{c}30 \\
{[0.2]}\end{array}$ & $\begin{array}{c}4 \\
{[0.1]}\end{array}$ \\
\hline $\begin{array}{r}\text { Population } \\
\text { density * }\end{array}$ & 6.25 & 4.69 & 7.81 & 6.25 & 6.25 & 6.25 & 6.25 & 6.25 & 6.26 & 6.26 & 7.82 & 6.25 & 6.25 & 6.25 & 6.25 \\
\hline $\begin{array}{r}\text { Total } \\
\text { number of } \\
\text { peasant } \\
\text { households }\end{array}$ & 40000 & 30000 & 50000 & 40000 & 40000 & 40000 & 40000 & 40000 & 40033 & 40042 & 50028 & 40000 & 40000 & 40000 & 40000 \\
\hline
\end{tabular}

615 
Table 8. Mean number (and standard error of the mean in brackets) of population clusters classified by size (in number of peasant households) in 1200 for 20 computation replications of each scenario. Grey cells: variable values that differ noticeably from the values in scenario $\alpha$. Small differences with the total number of population clusters displayed in Table 7 result from rounding the numbers.

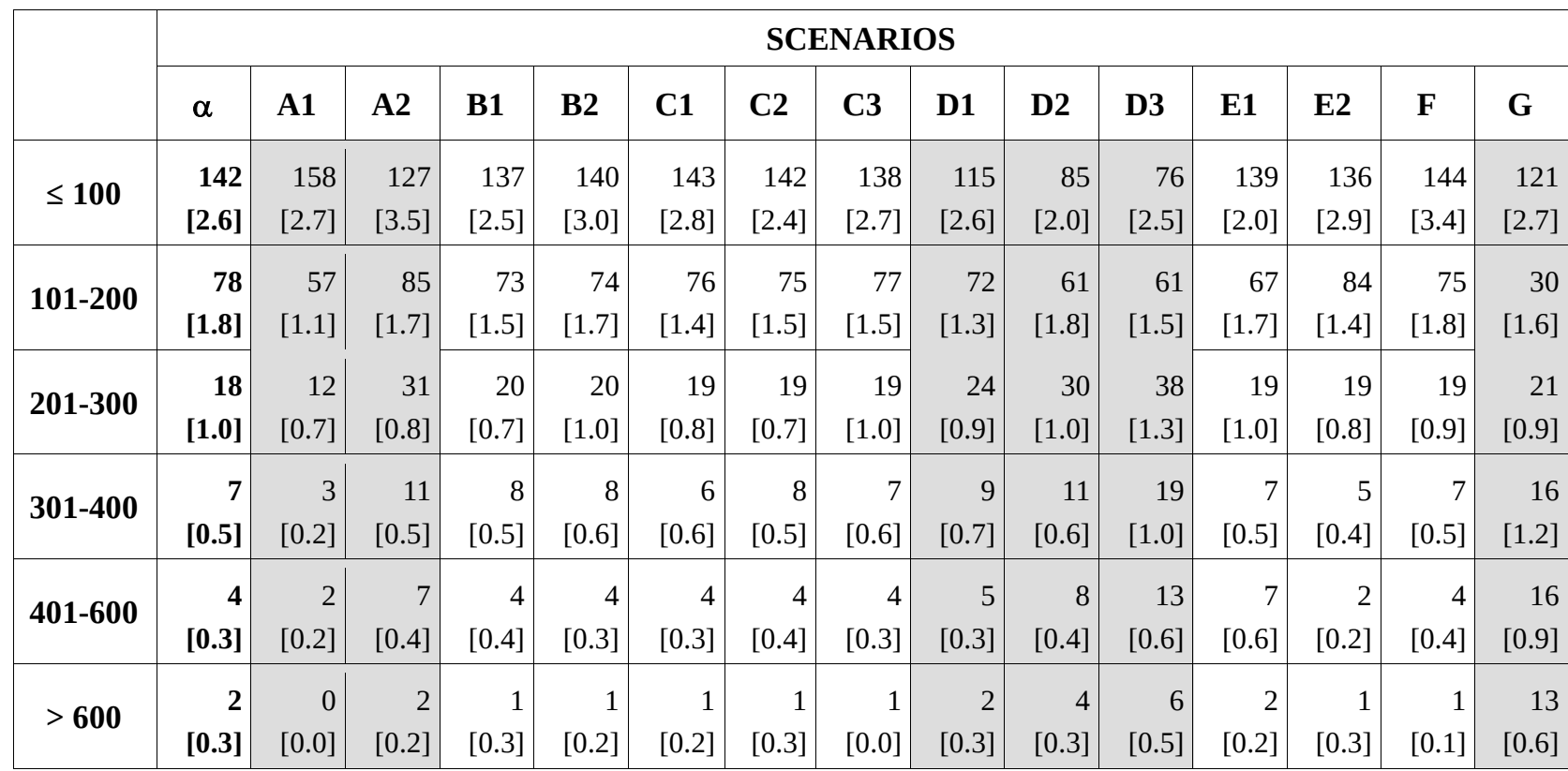

Figure 7. Mean percentage of population clusters classified by size (in number of peasant households) in 1200 for 20 computation replications of each scenario. Standard errors of the mean are comprised between 625 zero and one percent.

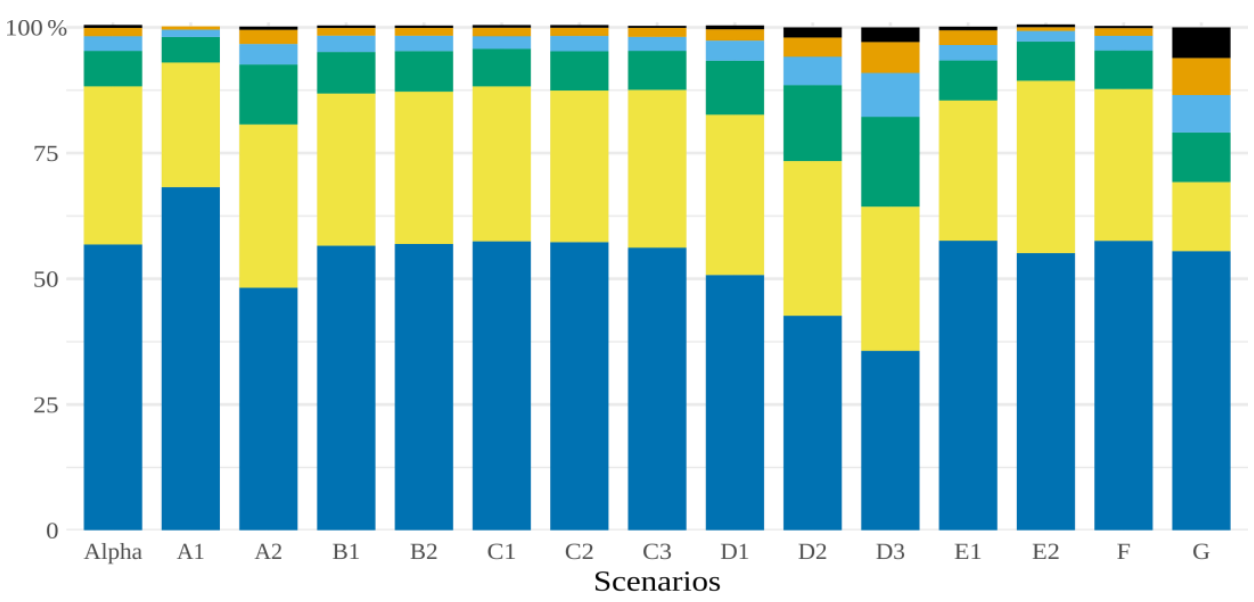

Size of population clusters (in number of peasant households)

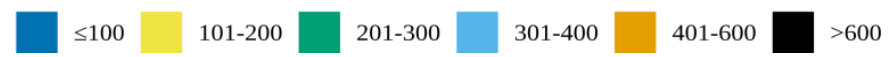


Table 9. Size of the four biggest population clusters (in number of peasant households) in 1200. Mean size and standard error of the mean of 20 computation replications of each scenario. Grey cells: variable values that differ noticeably from the values in scenario $\alpha$.

\begin{tabular}{|c|c|c|c|c|c|c|c|c|}
\hline \multirow{3}{*}{ Scenario } & \multicolumn{8}{|c|}{ Cluster rank } \\
\hline & \multicolumn{2}{|c|}{1} & \multicolumn{2}{|c|}{2} & \multicolumn{2}{|c|}{3} & \multicolumn{2}{|c|}{4} \\
\hline & Mean & s.e. & Mean & s.e. & Mean & s.e. & Mean & s.e. \\
\hline$\alpha$ & 548 & 21 & 478 & 14 & 447 & 8 & 423 & 7 \\
\hline A1 & 441 & 13 & 382 & 9 & 345 & 8 & 322 & 6 \\
\hline A2 & 702 & 32 & 580 & 14 & 547 & 13 & 503 & 9 \\
\hline B1 & 588 & 25 & 489 & 18 & 449 & 16 & 414 & 10 \\
\hline B2 & 582 & 32 & 501 & 15 & 445 & 12 & 420 & 10 \\
\hline C1 & 586 & 31 & 510 & 16 & 446 & 6 & 417 & 5 \\
\hline $\mathrm{C} 2$ & 544 & 14 & 484 & 12 & 438 & 8 & 409 & 7 \\
\hline C3 & 591 & 33 & 497 & 12 & 464 & 11 & 436 & 9 \\
\hline D1 & 656 & 32 & 543 & 15 & 504 & 15 & 462 & 10 \\
\hline D2 & 884 & 29 & 768 & 25 & 670 & 15 & 611 & 13 \\
\hline D3 & 1137 & 72 & 894 & 26 & 813 & 24 & 734 & 26 \\
\hline E1 & 722 & 35 & 605 & 19 & 530 & 14 & 492 & 9 \\
\hline E2 & 515 & 21 & 429 & 18 & 378 & 5 & 353 & 5 \\
\hline $\mathbf{F}$ & 564 & 24 & 492 & 16 & 444 & 10 & 411 & 8 \\
\hline G & 1380 & 55 & 1156 & 35 & 1087 & 35 & 987 & 31 \\
\hline
\end{tabular}

Simulated changes in the total number of peasant households in the study area (scenarios A1 and A2) exert a small but non-negligible effect. In scenario A1, the number of small population clusters 635 (with fewer than 100 peasant households) in 1200 is slightly higher than in scenario $\alpha$ and the largest clusters are noticeably smaller (Table 8). By contrast, in scenario A2, the number of small clusters is slightly lower, the number of medium-sized clusters is slightly higher, and the largest clusters are noticeably larger. Nevertheless, the overall shape of the rank-size distributions of population clusters at five points in time is the same for the three scenarios (A1, A2 and $\alpha$ 640 Figures 6, 8 and 9).

Figure 8. Rank-size distributions of population clusters obtained with scenario A1 at five dates. 


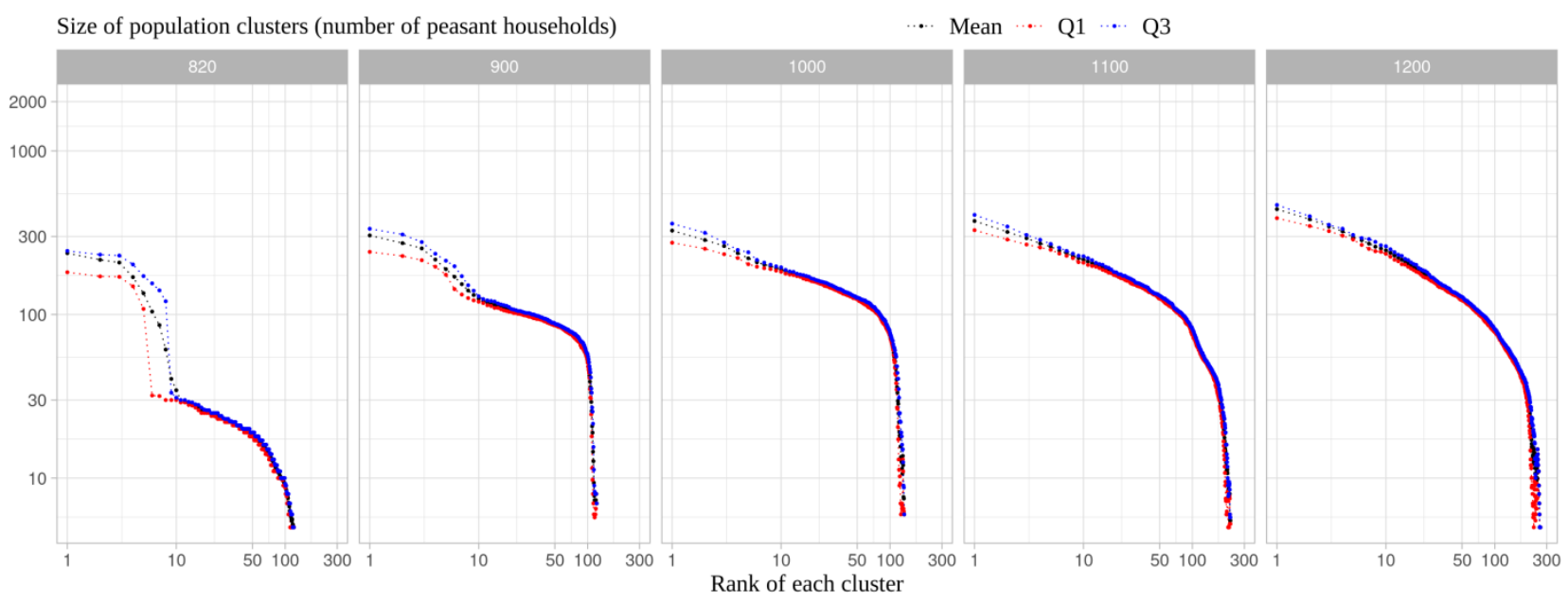

Figure 9. Rank-size distributions of population clusters obtained with scenario A2 at five dates.

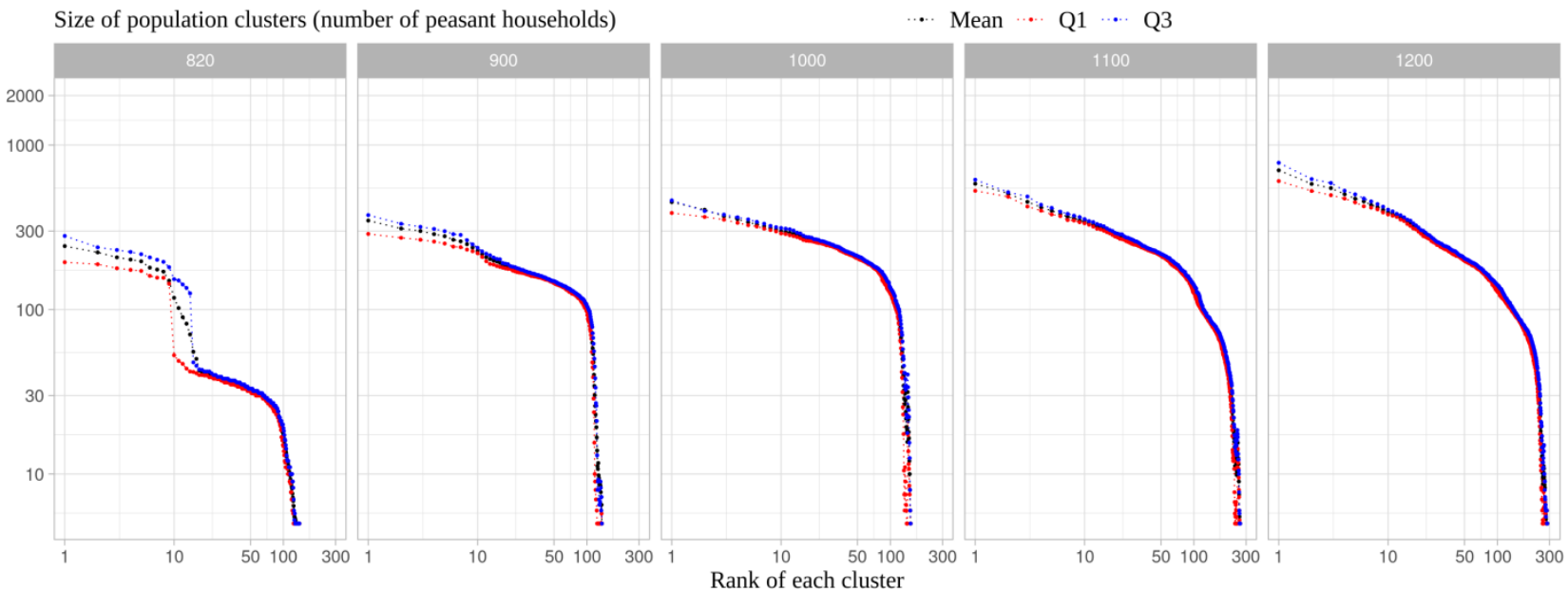

Introducing demographic growth (scenarios D1, D2 and D3) greatly increases the concentration and the hierarchy of the settlement pattern over time. For these scenarios, the number of population clusters and the proportion of dispersed households in 1200 are lower than for scenario $\alpha$. Moreover, settlement patterns simulated with scenarios D1 and D2 have fewer small clusters and more medium and large clusters in 1200 than in scenario $\alpha$ whereas scenario D3 has fewer small clusters and more medium and large clusters in 1200 than in scenario A2. The number of population

650 clusters in 1200 depends on both the initial number of peasant households in 800 and the intensity of demographic growth. By contrast, the hierarchy of the simulated settlement patterns seems to vary with the intensity of demographic growth only. Indeed, we observe that scenario D1 has more small clusters and fewer medium and large clusters in 1200 than scenario D2; scenario D2 has more small clusters and fewer medium and large clusters in 1200 than scenario D3. We also observe that the four biggest clusters are smaller in scenario D1 than in scenario D2 and even smaller than in scenario D3.

Figure 10. Rank-size distributions of population clusters obtained with scenario D1 at five dates. 


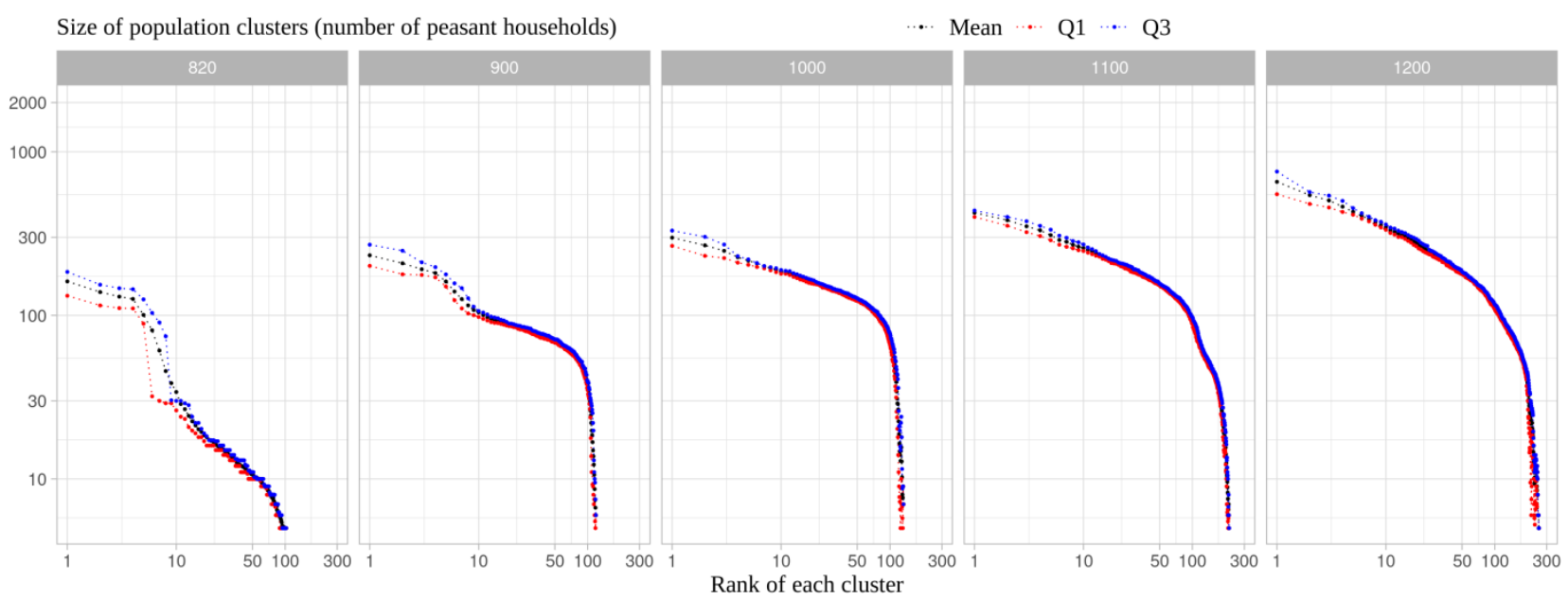


Figure 11. Rank-size distributions of population clusters obtained with scenario D2 at five dates.

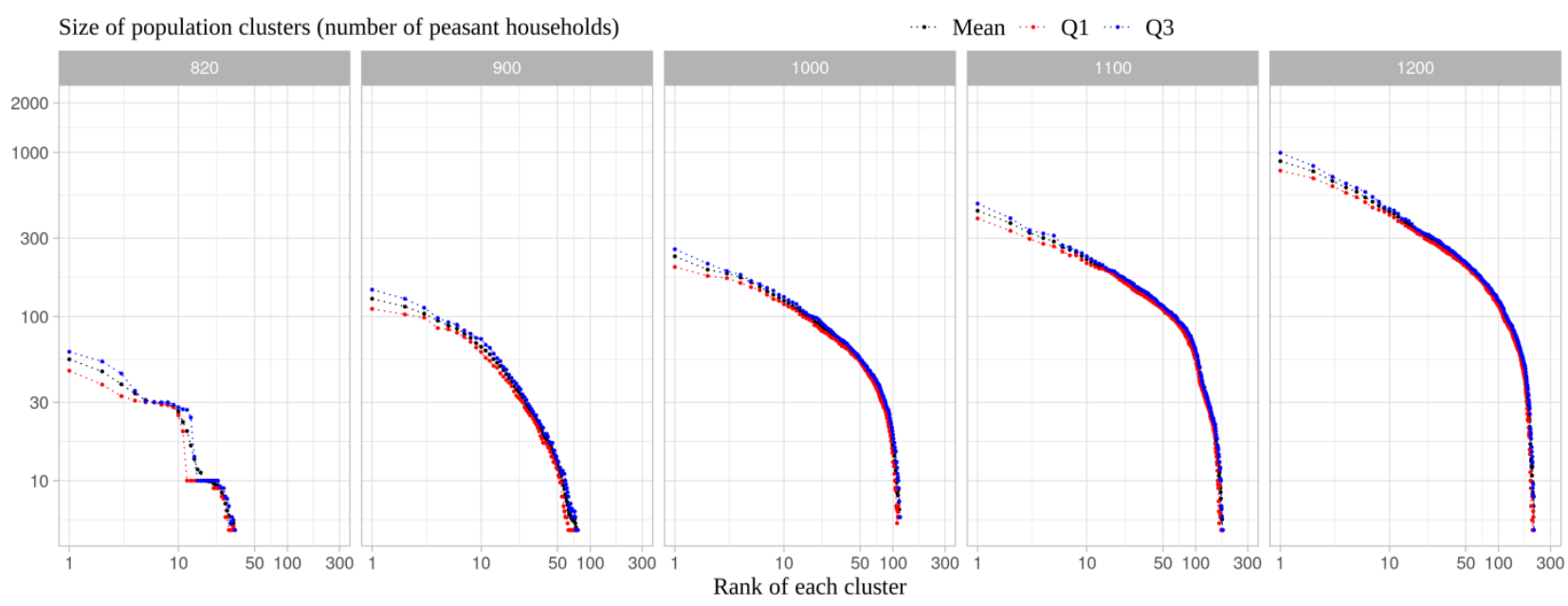

Figure 12. Rank-size distributions of population clusters obtained with scenario D3 at five dates.

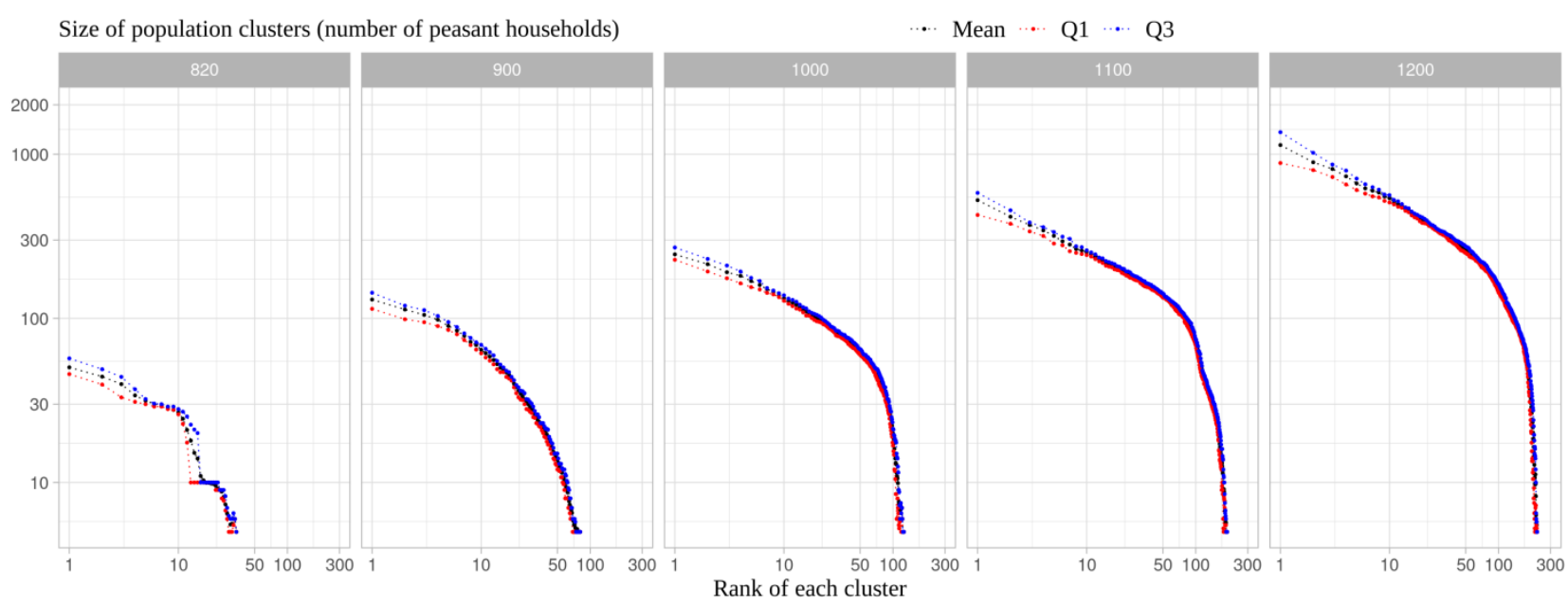

Figure 13. Rank-size distributions of population clusters obtained with scenario $G$ at five dates.

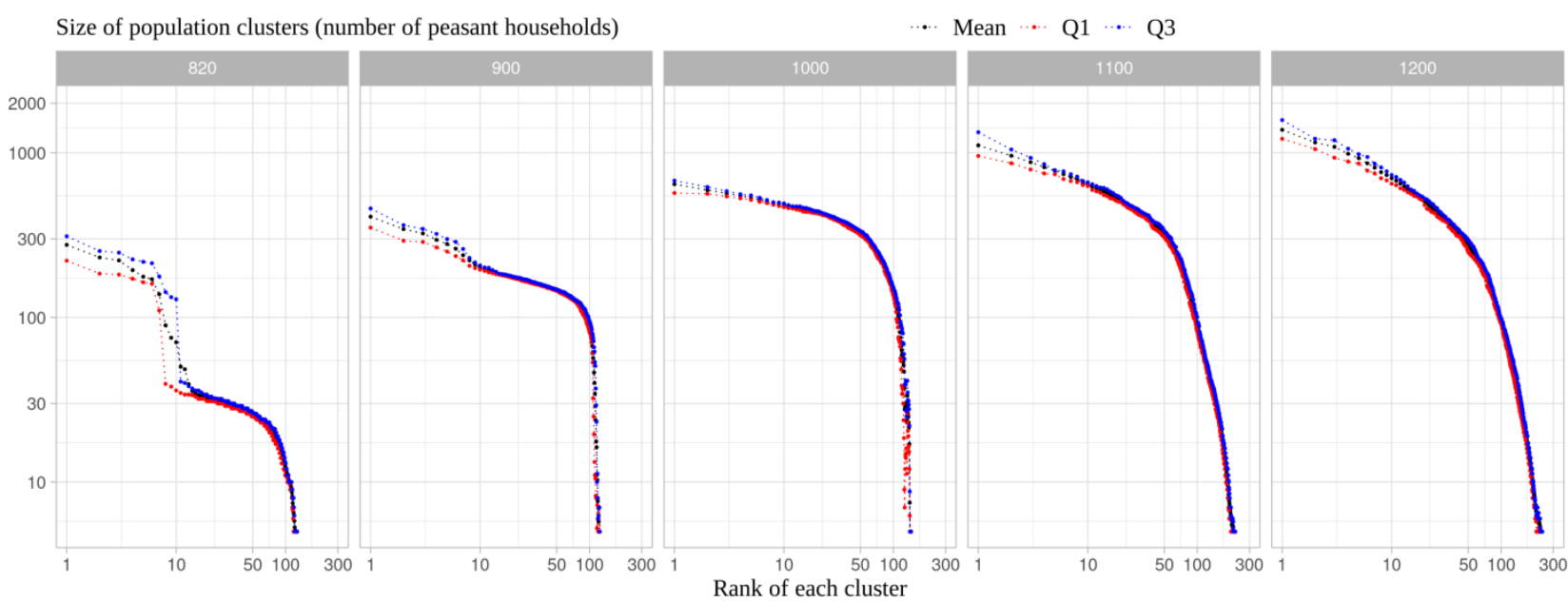


670 At the very beginning of the simulation, the concentration level (number of population clusters and sizes of the largest clusters) in scenario $\alpha$ is higher than in scenario D1 and, a fortiori, than in scenarios D2 and D3. The difference in population density may explain this phenomenon: when peasant households are closer to each other, they can cluster more easily. Incidentally, at the beginning of the simulation, the density is higher in scenario $\alpha$ than in scenario D1 and, a fortiori, 675 than in D2 and D3. A consequence of this phenomenon, combined with the intensity of demographic growth, is that the settlement pattern hierarchy increases more steadily in scenarios D2 and D3 than in scenario D1 and, a fortiori, than in scenario $\alpha$ (see Figures 10, 11 and 12, and Figure 6).

Figure 14. Proportion of peasant households relocating at each simulation step.
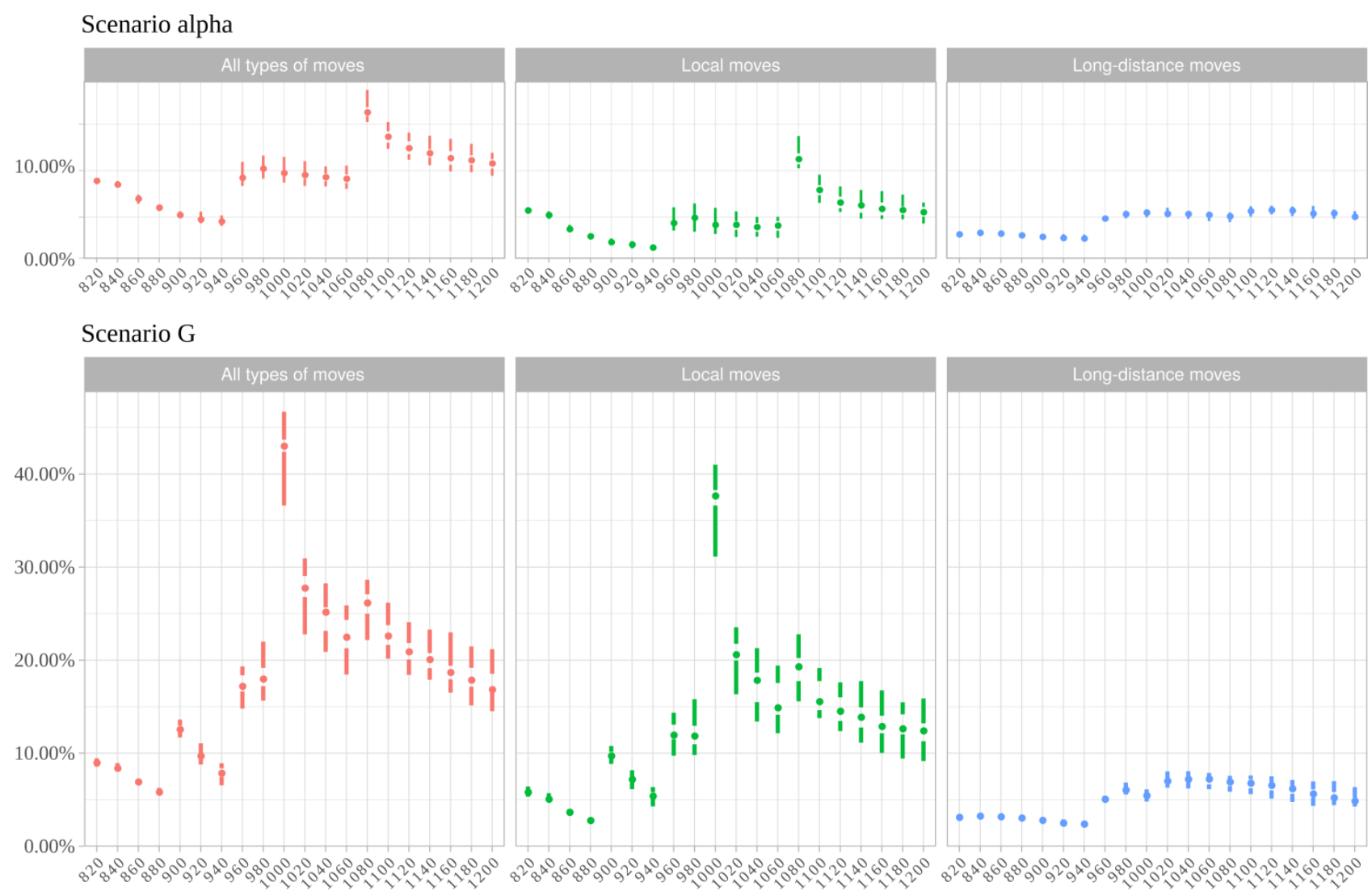

Increasing the radius of the local relocation of peasant households strongly favours their concentration: the proportion of scattered households in 1200 is extremely low (4\% compared to $30 \%$ in scenario $\alpha$ ), the number of population clusters in 1200 is also quite low, and the four largest 685 population clusters in 1200 are especially large compared to all other scenarios. The high concentration of peasant households simulated with scenario $G$ is explained by the large proportion of peasant households that relocate locally at each simulation step, in particular after the year 1000 (Figure 14). Interestingly, the proportion of long-distance relocations is not changed from that in scenario $\alpha$. The shapes of the rank-size distributions of population clusters are roughly similar to 690 those in scenario A2 (Figures 9 and 13). This can be explained by the fact that the number of peasant households is higher in scenario A2 than in scenario G but, as they are more dispersed in the first case, the number of peasant households within population clusters can be equivalent. Nevertheless the distribution of clusters according to their size classes is markedly different for the two scenarios (Figure 7).

695 The number of parish churches created at each simulation step co-varies with the total number of peasant households in the study area according to the mechanisms modelled in SimFeodal. Thus 
for instance, the number of parish churches in 1200 is almost the same in scenarios $G$ and $\alpha$. On the contrary, it is lower in scenarios D1, D2 and D3 and falls within the range of values expected from the empirical data (Table 4). Apart from the number of parish churches, their location too may differ widely between scenarios. For example, in scenario G, more parish churches are created within population clusters and fewer parish churches are created outside population clusters than in scenario $\alpha$. This in turn reinforces the attraction of existing population clusters, which finally increases the concentration and the hierarchy of the simulated settlement pattern.

\section{Discussion}

In all the simulated scenarios, with or without demographic growth, what is a scattered and nonhierarchical regional settlement pattern in 800 becomes concentrated and hierarchical by 1200 . The 710 number of population clusters and their size vary depending on the initial number of peasant households in the study area. When numerous peasant households are present in the study area from the very beginning of the simulation, some population clusters are already large from the first simulation step (year 820) (see Figures 6, 8, 9 and 13) although the rules that incite peasant households to relocate are not very constraining at this time period.

Figure 15. Change in the number of population clusters over time (mean and 1st and 3rd quartiles) for scenario D2.

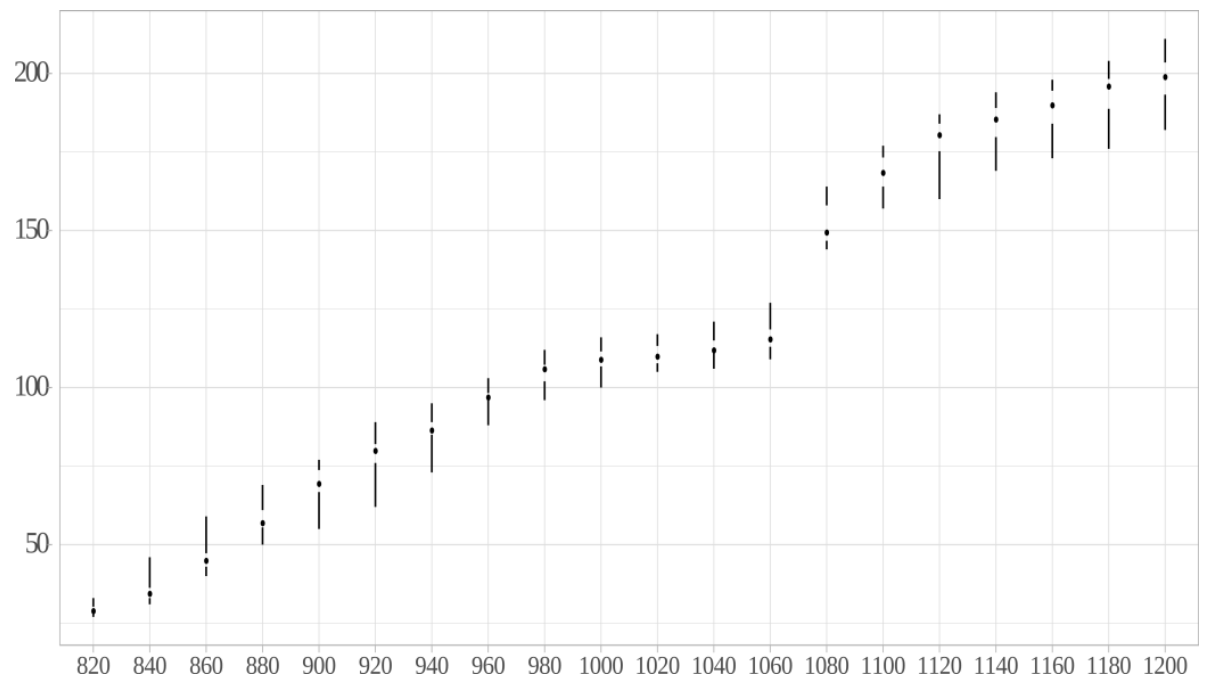

When demographic growth is simulated, the settlement pattern hierarchy increases more progressively over time and the final hierarchy reached by 1200 is more regular than that produced without demographic growth. The number of population clusters also increases more steadily as shown for scenario D2 in Figure 15 compared with scenario $\alpha$ in Figure 4. Indeed, cumulative processes and positive feedback loops in SimFeodal are only fully expressed if the number of peasant households increases over time. This can be illustrated by the creation of parish churches. If many peasant households are present right from the beginning of the simulation, more churches are created early in the simulation. At this time period, the requirement to be close to a church is weak. Consequently, many churches are created outside any cluster and these creations do not

730 increase the existing concentration and hierarchy of the settlement pattern. Conversely, if few peasant households are present at the beginning of the simulation, few churches are created early 
on. Then, as a consequence of demographic growth, the number of churches created increases. As the requirement to be close to a church strengthens over time, most churches are created within population clusters. Thus step by step, the creation of new churches increases the existing concentration and hierarchy of the settlement pattern.

In SimFeodal, each mechanism does not fully determine the level of concentration and hierarchy of the simulated settlement pattern because it interacts with other mechanisms. For example, one mechanism requires that peasant households appearing in the course of the simulation are placed

740 in a population cluster chosen according to a probabilistic lottery weighted by the number of peasant households in each cluster. In this way, the mechanism favours the concentration of population in existing clusters and peasant households have more chances of being placed in a large cluster than in a small one. This process mainly affects scenarios with demographic growth as more households appear in the course of simulation than in scenarios with no demographic

745 growth. Nevertheless, we observe the emergence of hierarchy and concentration even without demographic growth, which shows that this mechanism is not a crucial determinant of the simulated dynamics.

\subsection{Confronting the hierarchy of the simulated settlement patterns in 1200 with empirical knowledge in the field}

The hierarchy of urban centres is based on the combination of a series of descriptive criteria to produce a rank-order based on cumulative functions: the presence of a command centre or administration, military facilities, religious facilities, public and private facilities (town hall, bell tower, etc.) and so on. Considering this, we can estimate that the region of Touraine had 12-15 755 noteworthy population clusters (small towns) in the late Middle Ages (Galinié \& Audinet 1992; Joly 1997; Zadora-Rio 2014). If we consider that clusters are noteworthy when they have at least 400 peasant households, only scenario D2 has close to 12 of these biggest clusters. Scenarios D3 and $\mathrm{G}$ have too many large clusters and the other scenarios too few. If, however, we consider that the threshold size is 300 peasant households, then scenario $\alpha$ and its variants B1, B2, C1, C2, C3 760 and $\mathrm{F}$ fall in with the empirical estimation of 12 clusters.

The number of inhabitants is considered to have peaked in the thirteenth century in Northern France. Then in the mid-fourteenth century, the Great Plague produced a dramatic demographic collapse. Population growth set in again in the late seventeenth or early-eighteenth century, with the number

765 of inhabitants recovering to the level of the thirteenth century (Biraben 1976). Knowing this, it is possible to set the simulation results against historical and archaeological data for the eighteenth century. According to Maillard (1998), almost half of the parishes in Touraine had fewer than 100 peasant households in the early eighteenth century. Settlement patterns simulated with scenarios A2, D1 and D2 correspond to this empirical situation in 1200. In scenario D3, only $35.7 \%$ of

770 population clusters have fewer than 100 households whereas in the other scenarios, the proportion is higher (around 56\%). Another point concerns the size of the biggest population clusters reached at the end of the simulation. In 1789, the three biggest towns in Touraine (excluding Tours) numbered 1456 households for Amboise, 1331 households for Chinon, and 1031 households for Loches (Maillard 1998). If we assume that the number of peasant households in each cluster in

7751200 cannot be higher than it was in 1789, the largest clusters are in all probability too large in scenario G. 


\subsection{On the emergence of more or less hierarchical regional settlement patterns}

780 A number of scholars have identified different mechanisms that can produce hierarchical site size distributions in settlement systems. Crema (2014) and Duffy (2015) especially have provided interesting and complementary literature reviews. The latter lists six mechanisms: seasonal occupation (people use some sites for a restricted time of the year), cyclical aggregation and dispersal of a population, fission of villages into daughter communities due to population growth,

785 differences in productive catchment (resource richness allows some settlements to grow larger than others), functional specialisation of some sites, and regional political hierarchy. Of these six mechanisms SimFeodal models functional specialisation alone. At the beginning of the simulation in 800, the only focal points are the parish churches randomly distributed across the study area. At this point in time, they are not very attractive: peasant households accept to travel quite long

790 distances to the nearest church because they do not need to attend frequently. Then, new focal points appear, namely castles and village communities, which become increasingly attractive over time. Finally, as the attractiveness of population clusters becomes ever more differentiated, the hierarchy of the settlement system tends to increase. Concomitantly, the multiplication of castles and parish churches results in the creation of new population clusters around them, which tends to reduce the

795 concentration of peasant households in a fixed set of clusters. Introducing more functional specialisation into SimFeodal, especially by taking into account the presence of markets as well as other craft and commercial activities in some places, might increase the hierarchy of simulated settlement patterns. Yet Maillard (1998) observes that some market towns in the diocese of Tours in the eighteenth century were smaller than big villages.

800

Besides the mechanism of functional specialisation, SimFeodal contains other mechanisms that also influence the changes in the simulated settlement patterns. In particular, the push-pull relocation process of peasant households means that not only do highly attractive places actually attract population but also that weakly attractive places with a high level of taxation by lords are repellent.

805 On a regional scale, although no processes of competition or complementarity between centres of attraction are modelled, the spacing between them is constrained in two ways. First, a distance threshold ensures that a newly built castle is not too close to existing castles. Second, the size of the catchment areas of parish churches cannot be too large (in order to avoid peasant households travelling long distances to the nearest church) but, concomitantly, they cannot be too small as they

810 must contain a minimum number of households (in order to support the upkeep of the church and its clergy). Last but not least, global political and social changes occurring between 800 and 1200 are represented via contextual parameters that modify the behaviours of the lords and the peasant households over time (see Table 3 and Figure 3).

815 With all these mechanisms and contextual parameters, SimFeodal takes into account both induced and inherent spatial dependencies as defined by Fortin and Dale (2005) and discussed by Crema (2014). Induced spatial dependencies refer to the effect of variables external to the system of interest (e.g. contextual parameters representing global political and social changes in SimFeodal), while inherent spatial dependencies refer to intrinsic properties of the generative process that can be

820 manifested in the form of forces of repulsion (e.g. territorial spacing between settlements) and attraction (e.g. clusters of households committed to cooperative tasks). Crema (2014) suggests that ecological, anthropological and archaeological theories of group formation have implicitly emphasised the importance of one form of spatial dependence over another. By contrast, both forms are present and equally important in SimFeodal.

A question you may want to ask about the SimFeodal model is whether it is able to produce settlement patterns that are neither concentrated, nor hierarchical. The answer is: yes, it can, but not with plausible values of parameters. To illustrate this, we provide here the example of a scenario in 
which all values of parameters are the same as in scenario $\alpha$ except the value of the parameter "Maximum radius for local relocation of peasant households" set to $1000 \mathrm{~m}$. instead of $2500 \mathrm{~m}$. by default (see Appendix A). A maximum radius of $1000 \mathrm{~m}$. for local relocation of peasant households is very narrow. With this value of parameter, the level of hierarchy of the simulated settlement pattern in 1200 is very low as shown by Table 10 . The overwhelming majority of the population clusters are small and have about the same size. Moreover, the concentration level is also low since $83563 \%$ of the peasant households are still scattered in 1200.

Table 10. Mean percentage of population clusters classified by size (in number of peasant households) in 1200 for 20 computation replications of each scenario.

\begin{tabular}{|l|r|r|r|r|r|r|}
\hline & $\mathbf{1 0 0}$ & $\mathbf{1 0 1 - 2 0 0}$ & $\mathbf{2 0 1 - 3 0 0}$ & $\mathbf{3 0 1 - 4 0 0}$ & $\mathbf{4 0 1 - 6 0 0}$ & \multicolumn{1}{c|}{$\mathbf{6 0 0}$} \\
\hline Scenario $\alpha$ & 56.8 & 31.4 & 7.0 & 2.9 & 1.6 & 0.6 \\
\hline Tested scenario & 82.6 & 12.4 & 3.4 & 1.0 & 0.7 & 0.4 \\
\hline
\end{tabular}

840

\section{Conclusion}

We have simulated a series of 15 scenarios (including the basic scenario $\alpha$ ) with SimFeodal in order to better understand how certain social and demographic parameters influence the level of concentration and hierarchy emerging in rural regional settlement patterns in North-Western Europe

845 during the Middle Ages. According to the processes modelled in SimFeodal, it appears that demographic growth is not the primary cause of the increasing hierarchy of regional settlement patterns. However, introducing demographic growth into the simulated scenarios enables us to obtain simulation results closer to the empirical data. Moreover, both the number of population clusters and the hierarchy of the simulated settlement patterns increase more progressively over

850 time than without demographic growth. Interestingly enough, the size of villages and small towns in 800 , the proportion of peasant households moving only locally, and the power of village communities do not seem to influence the level of concentration and hierarchy of simulated settlement patterns. By contrast, increasing the radius of local relocation of peasant households has a strong effect but the resulting simulated patterns appear quite unrealistic when set against 855 empirical data.

In this way, we have used agent-based modelling to facilitate our understanding of past changes rather than as mechanisms for simply recreating the known past (Laue 2018). As recommended by Crema (2018), we have paid much attention to the fit (or the lack thereof) between simulation 860 outputs and observed data as well as the broader implications of the whole exercise instead of focusing exclusively on model building and description. In time, multiplying computer-based experiments based on explicit spatial simulations should help researchers to identify and formalise general laws for determining the concentration and dispersion of human settlements. This should also facilitate the identification of specific local features emerging in various social, cultural and political 865 contexts.

\section{References}

Amblard, F., Bommel, P., Rouchier, J. (2007). Assessment and validation of multi-agent models. In D. Phan, 870 F. Amblard (eds) Agent-based modelling and simulation in the social and human science, Bardwell Press, Oxford, 93-114. 
Axelrod, Robert, 1997. The Dissemination of Culture: A Model with Local Convergence and Global Polarization. J. Conf. Resolut. 42 (2), 203-226.

Barton, C.M., Ullah, I., Bergin, S.M., Mitasova, H., Sarjoughian, H. (2012). Looking for the future in the past: long-term change in socioecological systems. Ecological Modelling, 241, 42-53.

Ben-Akiva, M., \& de Palma, A. (1986). Analysis of a dynamic residential location choice model with transaction costs. Journal of Regional Science, 26(2), 321-341.

Bintliff, J., Sbonias, K. (Eds) (1999). Reconstructing Past Population Trends in Mediterranean Europe (3000 BC-AD 1800), The Archaeology of Mediterranean Landscapes 1, Oxbow Books, Oxford.

880 Biraben, J.-N. (1976). Les hommes et la peste en France et dans les pays européens et méditerranéens. Tome I : La peste dans l'histoire. Tome II : Les hommes face à la peste. Paris-La Haye, Mouton.

Bourin, M., Durand, R. (1984). Vivre au village au Moyen Age. Les solidarités paysannes du XIe au XIIIe siècle. Paris, Messidor-Temps actuels.

Boussard, J. (1962). L'origine des familles seigneuriales dans la région de la Loire moyenne. Cahiers de 885 civilisation médiévale, 19, 303-322.

Cegielski, W.H., Rogers, D.J. (2016). Rethinking the role of Agent-Based Modeling in archaeology. Journal of Anthropological Archaeology, 41, 283-298.

Chamberlain, A. (2006). Demography in Archaeology, Cambridge University Press.

Chapman, J. (1999). Archaeological Proxy-data for Demographic Reconstructions : Facts, Factoids of

890 Fiction? In J. Bintliff and K. Sbonias, Reconstructing Past Population Trends in Mediterranean Europe (3000 BC-AD 1800), Oxbow Books, Oxford, 65-76.

Chédeville, A. (1973). Chartres et ses campagnes (XIe-XIIIe siècle). Paris, Garnier, 1991 (1 ère éd. 1973).

Chérel, G., Cottineau, C., Reuillon, R. (2015). Beyond Corroboration: Strengthening Model Validation by Looking for Unexpected Patterns, PLoS One, 10(9), e0138212.

895 Chevalier, B. (1981). Aux origines du département d'Indre-et-Loire : l'ancien diocèse de Tours. In: Atlas de la région Centre. Tours, planche 9-1.

Crabtree, S.A., Bocinksy, R.K., Hooper, P.L., Ryan, S.C., Kohler, T.A. (2017). How to Make a Polity (in the Central Mesa Verde Region). American Antiquity, 82(1), 71-95.

Crema, E.R. (2014). A Simulation Model of Fission-Fusion Dynamics and Long-Term Settlement Change.

900 Journal of Archaeological Method and Theory, 21(2), 385-404.

Crema, E.R. (2018). Statistical inference and archaeological simulations. The SAA Archaeological Record, 18(2), 20-23.

Corriol, V. (2010). Les serfs de Saint-Claude. Etude sur la condition servile au Moyen Age. Rennes, Presses universitaires de Rennes.

905 Cura, R. (2020). Modéliser des systèmes de peuplement en interdisciplinarité. Co-construction et exploration visuelle d'un modèle de simulation. PhD thesis, University Paris 1 Panthéon Sorbonne.

Davies, B., Romanowska, I. (2018). An Emergent Community? Agent-Based Modelers in Archaeology. The SAA Archaeological Record, 18(2), 27-32.

Dean, J.S., Gumerman, G.J., Epstein, J.M., Axtell, R.L., Swedlund, A.C., Parker, M., McCarroll, S., 2000.

910 Understanding Anasazi culture change through agent-based modeling. In: Kohler, T.A., Gumerman, G.J. (Eds.), Dynamics in Human and Primate Societies: Agent-Based Modeling of Social and Spatial Processes. Oxford University Press, New York, 179-206.

Devroey, J.-P. (2003). Economie rurale et société dans l'Europe franque (VIe-IXe siècle). Fondements matériels, échanges et lien social. Paris, Belin.

915 Devroey, J.-P. (2009). Catastrophe, crise et changement social : à propos des paradigmes d'interprétation du développement médiéval (500-1100). In: Buchet, L. et al. Vers une anthropologie des catastrophes. Éditions APDCA, Antibes / INED, Paris, 139-161. 
del Castillo, F., Barceló, J.A., Mameli, L., Miguel, F., Vila, X. (2014). Modeling mechanisms of cultural diversity and ethnicity in hunter-gatherers. J. Archaeol. Method Theory 21, 364-384.

920 Duffy, P.R. (2015). Site size hierarchy in middle-range societies. Journal of Anthropological Archaeology, 37, 85-99.

Feller, L. (2007). Paysans et seigneurs au Moyen Age. VIIIe-XVe siècles. Paris, Armand Colin.

Edmonds, B., Moss, S., 2005. From KISS to KIDS - An 'Anti-simplistic' Modelling Approach. In: Davidsson, P., Logan, B., Takadama, K. (Eds.), Multi-Agent and Multi-Agent-Based Simulation. Joint

925 Workshop MABS 2004, New York, NY, USA, July 19, 2004, Revised Selected Papers. Springer, pp. 130 144.

Fortin, M.-J., Dale, M. (2005). Spatial analysis: A guide for ecologists. Cambridge, Cambridge University Press.

930126.

Fossier, R. (1982). Enfance de l’Europe, Xe- XIIe siècles. Aspects économiques et sociaux, Paris, P.U.F., 67-

Francovitch, R., Patterson, H., Barker, G. (2000). Extracting meaning from ploughsoil assemblages, Oxford, Oxbow.

Galinié, H., Audinet., I. (1992) Les villes et les agglomérations secondaires du bas Moyen Age : l’Indre-etLoire, XIVe-XVe siècle. In: Henri Galinié, Manuel Royo (dir.). Atlas des villes et des réseaux de villes en 935 région Centre, 1 . Tours, Archéa.

Gandini, C, Favory, F., Nuninger, L. (eds) (2012). Settlements pattern, production and trades from Neolithic to Middle Ages. Archaedyn. 7 millennia of territorial dynamics. Archaeopress, Bristish Archaeological Reports International Series 2370, Oxford.

Gauthiez, B., Zadora-Rio, E., Galinié, H. (Eds.) (2003). Village et ville au Moyen Age. Les dynamiques

940 morphologiques, Tours, Presses universitaires François-Rabelais.

Geary, P. (1994). Phantoms of Remembrance: Memory and Oblivion at the End of the First Millenium, Princeton University Press.

Grignard, A., Taillandier, P., Gaudou, B., Vo Duc, A., Huynh Nghi, Q., Drogoul A. (2013). GAMA 1.6 : Advancing the Art of Complex Agent-Based Modeling and Simulation. In: PRIMA 2013: Principles and 945 Practice of Multi-Agent Systems, Lecture Notes in Computer Science 8291, 117-131.

Guillot, O. (1972). Le comte d'Anjou et son entourage. Paris, Picard.

Hölzchen, E., Hertler, C., Timm, I., Lorig, F. (2016). Evaluation of Out of Africa hypotheses by means of agent-based modeling. Quaternary International, 413, 78-90.

Joly, S. (1997). Villes et agglomérations secondaires du XIIIe siècle en région Centre. In: Henri Galinié, 950 Manuel Royo (dir.). Atlas des villes et des réseaux de villes en région Centre, 3. Tours, Archéa.

Kohler, T.A., Bocinsky, R.K., Cockburn, D., Crabtree, S.A., Varien, M.D., Kolm, K.E., Smith, S., Ortman, S.G., Kobti, Z. (2012). Modelling prehispanic Pueblo societies in their ecosystems. Ecological Modelling, 241, 30-41.

Lake, M.W. (2014). Trends in archaeological simulation. Journal of Archaeological Method and Theory, 21, $955258-287$.

Lake, M.W. (2015). Explaining the past with ABM: on modelling philosophy. In: Wurzer, G., Kowarik, K., Reschreiter, H. (Eds.), Agent-Based Modeling and Simulation in Archaeology. Springer, London, 3-35.

Laue, C. (2018). Introduction to computer simulation and archaeology. The SAA Archaeological Record, 18(2), 16-16.

960 Lauwers, M., Schneider, L. (Eds.) (2020, in press). Mises en réserve. Production, accumulation et redistribution des céréales dans l'Occident médiéval et moderne. Presses universitaires du Midi, Toulouse.

Le Mée, R. (1989). Les villes de France et leur population de 1806 à 1851. Annales de démographie historiques 1989, 321-393. 
Leturcq, S., Mazel, F. (2021, forthcoming). Une dynamique d'expansion (VIIIe-XIe siècle). In: Mazel, F. (dir.). Nouvelle histoire du Moyen Age. Seuil, Paris.

Livet P., Müller J.-P., Phan D., Sanders L. (2010). Ontology, as a mediator for agent-based modeling in social science. Journal of Artificial societies and Social Simulation, 13(1), 3.

Lorans E. (1996), Le Lochois du haut Moyen Age au XIIIe siècle, Tours, Publications de l’Université de Tours.

970 Maillard, B. (1998). Les campagnes de Touraine au XVIIIe siècle - Structures agraires et économie rurale. Presses Universitaires de Rennes. Chap. 1: Hommes et territoires, pp 15-40.

Montgomery, D. C. (2019). Design and Analysis of Experiments, $10^{\text {th }}$ Edition. Wiley, E-Book.

Nissen Jaubert, A. (2012). Ruptures et continuités dans l'habitat rural du Moyen Age en Pays de la Loire. In: Alain Valais (dir.) L'habitat rural au Moyen Age dans le Nord-Ouest de la France. Presses universitaires

975 de Rennes, 295-314.

Nissen, A. (2014). L'habitat rural au Moyen Age. In: Elisabeth Zadora-Rio (dir.). Atlas Archéologique de Touraine. Tours, FERACF (http://a2t.univ-tours.fr/notice.php?id=80).

Montgomery, D.C., 2009. Design and Analysis of Experiments, 10th ed. Wiley, pp. E-Book.

Pellegrini, P., Fotheringham, A. (2002). Modelling spatial choice: A review and synthesis in a migration

980 context. Progress in Human Geography, 26(4), 487-510.

Premo, L. S. (2010). Equifinality and Explanation: Thoughts on the Role of Agent-based Modeling in Postpositivist Archaeology. In: Andre Costopoulos and Mark Lake (Eds) Simulating Change. Archaeology into the Twenty-First Century, University of Utah Press, Salt Lake City, 28-37.

Rogers, J.D., Nichols, T., Emmerich, T., Latek, M., Cioffi-Revilla, C. (2012). Modeling scale and variability

985 in human-environmental interactions in Inner Asia. Ecolological Modelling, 241, 5-14.

Rouse, L., Weeks, L. (2011). Specialization and social inequality in Bronze Age SE Arabia: analyzing the development of production strategies and economic networks using agent-based modeling. Journal of Archaeological Science, 38, 1583-1590.

Schmitt, C., Rey-Coyrehourcq, S., Reuillon, R., Pumain, D. (2015). Half a Billion Simulations: Evolutionary

990 Algorithms and Distributed Computing for Calibrating the SimpopLocal Geographical Model. Environment and Planning B: Planning and Design, 42(2), 300-315.

Tannier, C., Morer, M., Ansel, D. (2016), Spatial Decision Making: Between Individual Choices and Collective References (chap. 6), In: P. Frankhauser and D. Ansel (eds.) Deciding Where to Live - An Interdisciplinary Approach of Residential Choice in Social Context, Springer, 127-149.

995 Toubert, P. (2004). L'Europe dans sa première croissance. De Charlemagne à l'an mil. Fayard, Paris.

Varenne F. (2010). Les simulations computationnelles dans les sciences sociales. Nouvelles perspectives en sciences sociales, 52, 17-49.

Varenne F. (2016). La sous-détermination des modèles explicatifs par les lois empiriques : un problème récurrent mais fécond en géographie de modélisation. In C. Blanckaert, J. Léon, D. Samain (dir)

1000 Modélisations et sciences humaines - Figurer, interpréter, simuler, L'Harmattan, Paris, 85-102.

Vigil-Escalera Guirado, A., Bianchi, G., Quiros, J. A. (Eds.) (2013). Horrea, barns and silos. Storage and incomes in Early Medieval Europe. Universidad del Pais Vasco.

Von Bertalanffy, L. (1968). General System theory: Foundations, Development, Applications. New York: George Braziller.

1005 Wren, C. D. , Xue, J. Z., Costopoulos, A., Burke, A. (2014). The role of spatial foresight in models of hominin dispersal. Journal of Human Evolution, 69, 70-78.

Zadora-Rio E. (Ed.) (2008). Des paroisses de Touraine aux communes d'Indre-et-Loire : la formation des territoires, Tours, FERACF. 
Zadora-Rio, E. (2009). Early medieval villages and estate centres in France (c.300-c.1100). In: J. A. Quirós Castillo (Ed.). The archaeology of early medieval villages in Europe, Universidad del País Vasco, Bilbao, 77-98.

Zadora-Rio, E. (2014) (Ed.). Atlas Archéologique de Touraine. Tours, FERACF (http://a2t.univ-tours.fr/).

1010 Zadora-Rio, E. (2014a). Les châteaux du Moyen Age central (900-1200). In: Elisabeth Zadora-Rio (dir.). Atlas Archéologique de Touraine. Tours, FERACF (http://a2t.univ-tours.fr/notice.php?id=243).

Zadora-Rio, E. (2014b). Les fortifications de terre médiévales et leurs avatars: perspectives historiographiques, in Elisabeth Zadora-Rio (dir.). Atlas Archéologique de Touraine. Tours, FERACF (http://a2t.univ-tours.fr/notice.php?id=242).

Appendix A. Mechanism parameters of the SimFeodal model.

\begin{tabular}{|c|c|}
\hline Title & Value \\
\hline \multicolumn{2}{|l|}{ Peasant households } \\
\hline Maximum radius for local relocation of peasant households. & $2500 \mathrm{~m}$. \\
\hline Potential frequency of a non-dependent peasant household relocating far away. & 0.2 \\
\hline \multicolumn{2}{|l|}{ Population clusters } \\
\hline Minimum number of peasant households for creating a population cluster. & 5 \\
\hline $\begin{array}{l}\text { Maximum distance between peasant households or focal points beyond which they do } \\
\text { not belong to the same cluster. }\end{array}$ & $100 \mathrm{~m}$. \\
\hline \multicolumn{2}{|l|}{ Lords } \\
\hline Probability of one among all small lords building a castle at each simulation step. & 0.5 \\
\hline $\begin{array}{l}\text { When a small lord appears in the simulation, probability that he can collect rents (via the } \\
\text { creation of a tax area). }\end{array}$ & $0.1(10 \%)$ \\
\hline $\begin{array}{l}\text { Probability of a small lord creating a new tax area for collecting other rights in his } \\
\text { neighbourhood at each simulation step. }\end{array}$ & $0.15(15 \%)$ \\
\hline Minimum and maximum radius of tax areas created by small lords, apart from castles. & $\begin{array}{l}1000 \mathrm{~m} . \\
5000 \mathrm{~m} .\end{array}$ \\
\hline $\begin{array}{l}\text { Among all peasant households within the tax area of a small lord (apart from castles), } \\
\text { minimum and maximum percentage of peasant households that pay fees to this lord. }\end{array}$ & $\begin{array}{l}0.05(5 \%) \\
0.25(25 \%)\end{array}$ \\
\hline $\begin{array}{l}\text { Among all peasant households within the tax area of a castle, percentage of them that pay } \\
\text { fees to the castellan. }\end{array}$ & $1(100 \%)$ \\
\hline $\begin{array}{l}\text { At each simulation step and for each tax area of a small lord independently of each other } \\
\text { (apart from castles), probability of a small lord passing some of his rights on to another } \\
\text { lord. }\end{array}$ & $0.33(33 \%)$ \\
\hline $\begin{array}{l}\text { Maximum radius of the neighbourhood within which a small lord can pass some of his } \\
\text { rights on to other lords or build a castle. }\end{array}$ & $5000 \mathrm{~m}$. \\
\hline $\begin{array}{l}\text { When a small lord passes some rights to another lord (apart from castles), probability of } \\
\text { the recipient of the donation being located within the neighbourhood of the giver. The } \\
\text { maximum radius of this neighbourhood is set by the parameter exposed above. }\end{array}$ & $0.8(80 \%)$ \\
\hline $\begin{array}{l}\text { At each simulation step and for each castle owned by a lord, probability of the lord } \\
\text { passing custody of his castle to a small lord who is not already a castellan. }\end{array}$ & 0.5 \\
\hline \multicolumn{2}{|l|}{ Castles } \\
\hline $\begin{array}{l}\text { Minimum and maximum radius of tax areas associated with a castle. All tax areas of a } \\
\text { castle are of the same radius. }\end{array}$ & $\begin{array}{l}2000 \mathrm{~m} . \\
15000 \mathrm{~m} .\end{array}$ \\
\hline Minimum distance between a newly built castle and existing castles. & $3000 \mathrm{~m}$. \\
\hline
\end{tabular}




\begin{tabular}{|l|l|}
\hline Probability of a castle being built within a population cluster. & 0.5 (50\%) \\
\hline $\begin{array}{l}\text { Probability of a castle becoming a major castle when it is located in or close to a pole } \\
\text { containing at least one focal point in addition to the castle. }\end{array}$ & 0.8 \\
\hline Parish churches & 2000 \\
\hline $\begin{array}{l}\text { Weighting (in number of peasant households) of the probability of a new parish being } \\
\text { created within a population cluster. }\end{array}$ & 20 \\
\hline $\begin{array}{l}\text { Minimum number of dissatisfied peasant households required for the creation of a new } \\
\text { parish outside a population cluster. }\end{array}$ & 20 \\
\hline Attractive centres & 0.15 \\
\hline Attractiveness of a small castle & 0.25 \\
\hline Attractiveness of a major castle & 0.15 \\
\hline Attractiveness of a parish church & 0.25 \\
\hline Attractiveness of two parish churches & 0.50 \\
\hline Attractiveness of three parish churches & 0.60 \\
\hline Attractiveness of four or more parish churches & 0.15 \\
\hline Attractiveness of a village community & \\
\hline
\end{tabular}

Appendix B. Technical parameters of the SimFeodal model.

\begin{tabular}{|c|c|}
\hline Title & Default value \\
\hline \multicolumn{2}{|l|}{ Peasant households } \\
\hline $\begin{array}{l}\text { Maximum fees paid by a peasant household beyond which it becomes fully } \\
\text { dissatisfied. }\end{array}$ & 15 \\
\hline $\begin{array}{l}\text { Minimum value of protection satisfaction when the distance from the peasant } \\
\text { household to the closest castle exceeds the distance beyond which a peasant } \\
\text { household is absolutely dissatisfied. }\end{array}$ & 0.01 \\
\hline \multicolumn{2}{|l|}{ Population clusters } \\
\hline Width of the buffer zone around the envelope of each cluster. & $100 \mathrm{~m}$. \\
\hline \multicolumn{2}{|l|}{ Lords } \\
\hline $\begin{array}{l}\text { High justice rights: fees collected by the lord owner of a tax area for each subjugated } \\
\text { peasant household. }\end{array}$ & 2 \\
\hline $\begin{array}{l}\text { High justice rights: fees received for each subjugated peasant household by the lord } \\
\text { who has passed his rights over the tax area to another lord. }\end{array}$ & 2.5 \\
\hline $\begin{array}{l}\text { Rents: fees collected by the lord owner of a tax area for each subjugated peasant } \\
\text { household. }\end{array}$ & 1 \\
\hline $\begin{array}{l}\text { Rents: fees received for each subjugated peasant household by the lord who has } \\
\text { passed his rights over the tax area to another lord. }\end{array}$ & 1.25 \\
\hline $\begin{array}{l}\text { Other rights: fees collected by the lord owner of a tax area for each subjugated } \\
\text { peasant household. }\end{array}$ & 0.25 \\
\hline $\begin{array}{l}\text { Other rights: fees received for each subjugated peasant household by the lord who has } \\
\text { passed his rights over the tax area to another lord. }\end{array}$ & 0.35 \\
\hline Number of successive draws of the probability of an overlord building a castle. & 3 \\
\hline Number of successive draws of the probability of a small lord building a castle. & 1 \\
\hline
\end{tabular}


Appendix C. SimFeodal software application: Graphical User Interface. On the map, black points represent peasant households, small red disks represent castles, large disks represent tax areas.
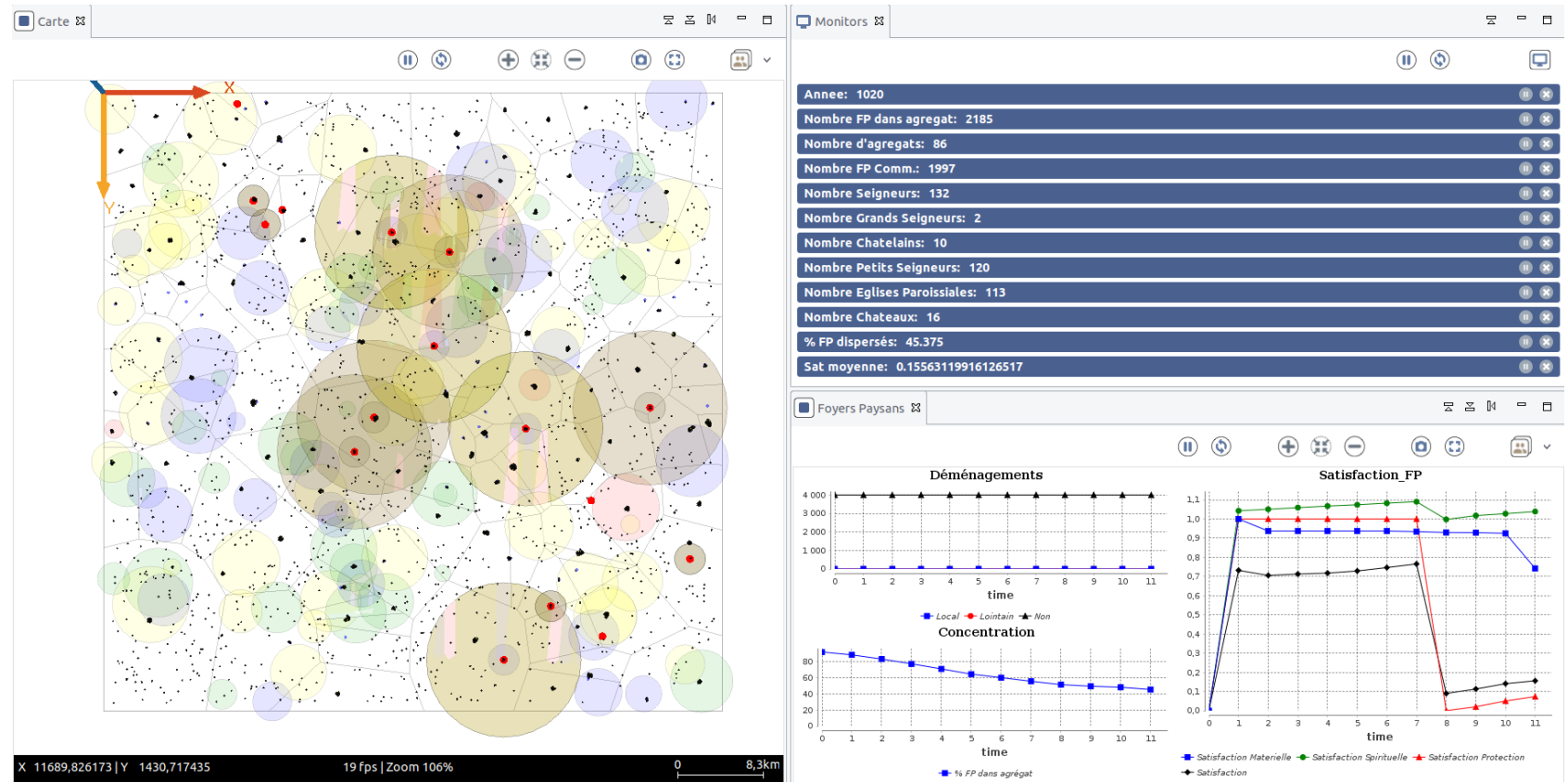